\title{
A cloned human cDNA determines expression of a mouse stage-specific embryonic antigen and the Lewis blood group $\alpha(1,3 / 1,4)$ fucosyltransferase
}

\author{
Jolanta F. Kukowska-Latallo, ${ }^{1}$ Robert D. Larsen, ${ }^{1}$ Rajan P. Nair, ${ }^{1}$ and John B. Lowe ${ }^{1,2,3}$ \\ ${ }^{1}$ Howard Hughes Medical Institute and the Department of Pathology, The University of Michigan Medical School, Ann Arbor, \\ Michigan 48109-0650 USA
}

\begin{abstract}
The stage-specific embryonic antigen SSEA-1 is a cell-surface oligosaccharide molecule expressed with temporal precision during the murine preimplantation period and implicated in adhesive events involving the process of compaction. We used a mammalian transient expression system to isolate a cloned human cDNA that determines expression of the SSEA-1 molecule. The cDNA sequence predicts a type II transmembrane protein with a domain structure similar to mammalian glycosyltransferases, but without primary sequence similarity to these enzymes. The carboxy-terminal domain of this protein was shown to be catalytically active as a fucosyltransferase when expressed in COS-1 cells as a portion of a secreted protein A fusion peptide. The enzyme is an exceptional glycosyltransferase in that it can use both type I and type II oligosaccharides as acceptor substrates to generate subterminal Fuc $\alpha(1,4)$ - and Fuc $\alpha(1,3)$-linkages, respectively, in a manner analogous to the human Lewis blood group fucosyltransferase. Southern blot analysis shows that the cDNA corresponds to sequences syntenic to the Lewis locus on chromosome 19. These results indicate that this cDNA is the product of the human Lewis blood group locus, provide genetic confirmation of the hypothesis that this enzyme can catalyze two distinct transglycosylation reactions, and outline an approach to the isolation of other sequences that determine expression of developmentally regulated oligosaccharide antigens.
\end{abstract}

[Key Words: Stage-specific embryonic antigen; SSEA-1; fucosyltransferase; Lewis blood group; oligosaccharide; expression cloning]

Received March 12, 1990; revised version accepted May 8, 1990.

Most of the terminal oligosaccharide linkages that have been described, including those of the human $\mathrm{ABO}, \mathrm{H}$, Secretor, and Lewis blood groups (Watkins 1980), exhibit precise spatial and temporal expression patterns throughout the mammalian developmental process (Szulman 1960, 1962, 1963, 1965, 1971; Szulman and Marcus 1973; Solter and Knowles 1978; Pennington et al. 1985|. These patterns are discernible first on the surfaces of preimplantation and early postimplantation embryonic cell aggregates (Bird and Kimber 1984; Fenderson et al. 1984; Pennington et al. 1985; Fenderson et al. 1986; Kimber 1986). In the mature organism, expression of distinct oligosaccharide moieties ultimately becomes restricted to specific cell types (Szulman 1960, 1962; Watkins 1980; Dodd and Jessel 1985). Malignant transformation often imposes disorder on the adult patterns to yield aberrant oligosaccharide structures (Hakomori 1984; Kim et al. 1988). These anomalous structures often mirror the glycoconjugate arrays displayed during the embryonic development of the transformed tissue

${ }^{3}$ Corresponding author.
(Hakomori 1984; Feizi 1985). The precise function(s) of such oligosaccharide structures during development is not known. Recent information, however, suggests that these molecules may modulate adhesive events that occur during mammalian embryogenesis (Bird and Kimber 1984; Fenderson et al. 1984; Rutishauser et al. 1988; Eggens et al. 1989; Kojima and Hakomori 1989; Hall et al. 1990).

In general, the specific oligosaccharide structures displayed by a cell are a function of the set of glycosyltransferases it expresses (Sadler 1984; Kornfeld and Kornfeld 1985; Paulson and Colley 1989|. Because it has been thought that each glycosyltransferase can construct just a single distinct glycosidic linkage (Hagopian and Eylar 1968) and because a large number of such glycosidic linkages have been described (Beyer et al. 1982; Sadler 1984), it can be anticipated that glycoconjugate expression is determined by the coordinate regulation of many dozens of glycosyltransferase genes (Paulson and Colley 1989/. It is only recently, however, that molecular cloning approaches have been successfully applied to the isolation of glycosyltransferase sequences (e.g., see 
Weinstein et al. 1987; Shaper et al. 1988; Rajan et al. 1989; Joziasse et al. 1989; Larsen et al. 1989; Yamamoto et al. 1990). This is largely because these enzymes are found in small amounts in cells and are generally difficult to purify (e.g., see Weinstein et al. 1982; Clausen et al. 1990). Thus there is only a rudimentary understanding of the molecular details concerning regulation of oligosaccharide expression during embryogenesis.

One of the first developmentally regulated embryonic oligosaccharide antigens to be described was a fucosylated oligosaccharide molecule known as the stage-specific embryonic antigen SSEA-1 (Solter and Knowles 1978; Gooi et al. 1981). This antigen first appears on the surface of cells at the eight-cell stage of mouse embryogenesis and later becomes restricted to specific cell types during murine development (Solter and Knowles 1978; Pennington et al. 1985). Complementary experimental observations by two groups suggest that the SSEA-1 antigen may participate in adhesive events leading up to and involving compaction (Bird and Kimber 1984; Fenderson et al. 1984). Although the molecular nature of these processes is undefined, recent biochemical evidence suggests that homotypic carbohydrate-carbohydrate interactions between SSEA-1 molecules may be operative in this context (Eggens et al. 1989).

The SSEA-1 molecule consists of $\mathrm{N}$-acetyllactosamine, which has been modified by a fucose residue in $\alpha(1,3)$ linkage to the subterminal GlcNAc of this disaccharide (Table 1) (Gooi et al. 1981). The SSEA-1 determinant is formed by the action of one or more $\alpha(1,3) \mathrm{fu}$ cosyltransferases $[\alpha(1,3) \mathrm{FTs}]$ catalyzing a transglycosylation reaction between the nucleotide sugar substrate GDP-fucose and linear or branched oligosaccharide molecules terminating in the type II $\mathrm{N}$-acetyllactosamine moiety (Table 1) (Sadler 1984). This reaction attaches fucose in $\alpha$ anomeric glycosidic linkage to the C3 hydroxyl of the GlcNAc moiety (Table 1). A related structure, the Lewis a determinant (Table 1), is likewise constructed from type I precursors (terminating in lacto- $N$-biose I moieties, Table 1$)$ by an $\alpha(1,4)$ fucosyltransferase $[\alpha(1,4)$ FT $]$ that is thought to be the product of the human Lewis blood group locus (Watkins 1980). Interestingly, this enzyme apparently copurifies with an $\alpha(1,3) \mathrm{FT}$ ac- tivity that is also determined by the Lewis locus (Johnson et al. 1981; Prieels et al. 1981; Johnson and Watkins 1982). These observations have suggested the possibility that a single enzyme, encoded by the Lewis locus, has the exceptional ability to form two distinct glycosidic linkages.

The structures of mammalian fucosyltransferases and their genes, as well as the mechanisms that determine their expression, remain undefined. This is primarily because these enzymes are nonabundant and difficult to purify (Prieels et al. 1981; Eppenberger-Castori et al. 1989). Here, we report the application of a gene transfer scheme for the isolation of a cloned human CDNA that determines expression of the SSEA- 1 antigen and a cognate fucosyltransferase. Analysis of the substrate specificity of this enzyme indicates that it can catalyze transglycosylation reactions that yield both $\operatorname{Fuc} \alpha(1,4)$ and Fuc $\alpha(1,3)$-glycosidic bonds. These results demonstrate an exception to the "one enzyme, one linkage" hypothesis (Hagopian and Eylar 1968) and confirm the biochemical observations that suggested this possibility. On the basis of the acceptor substrate specificity determined in these experiments, and on chromosomal localization studies, we propose that this cloned cDNA encodes the product of the human Lewis blood group locus.

\section{Results}

Cloning approach

Biochemical and genetic studies have indicated that the human genome probably encodes at least two different $\alpha(1,3)$ FTs (Johnson et al. 1981; Sadler 1984; Tetteroo et al. 1987; Potvin et al. 1990) capable of constructing SSEA-1 structures. We developed a gene transfer system that would allow us to isolate cloned cDNAs encoding functional $\alpha(1,3 \mid$ FT molecules, or that otherwise determine $\alpha(1,3)$ FT expression, without the need to purify the enzyme first. This system instead exploits existing reagents that allow detection of the cell surface-expressed oligosaccharide product of these enzymes and that provide for specific assay of their enzymatic activity. In par-

Table 1. Names and structures of type I and type II disaccharide molecules and their fucosylated derivatives

\begin{tabular}{|c|c|c|c|}
\hline \multicolumn{2}{|l|}{ Type I molecules } & \multicolumn{2}{|l|}{ Type II molecules } \\
\hline Name & Structure & Name & Structure \\
\hline Precursor disaccharide (lacto- $N$-biose I) & Gal $\beta 1,3-G l c N A c$ & Precursor disaccharide ( $N$-acetyllactosamine) & Galß1,4-GlcNAc \\
\hline H Type I ( 2 '-fucosyllacto- $N$-biose I) & $\begin{array}{l}\text { Gal } \beta 1,3-G l c N A c \\
\mid \alpha 1,2 \\
\text { Fuc }\end{array}$ & H Type II (2'-fucosyllactos[amin]e) & $\begin{array}{l}\text { Gal } \beta 1,4-G l c[N A c] \\
\mid \alpha 1,2 \\
\text { Fuc }\end{array}$ \\
\hline Lewis a & $\begin{array}{c}\text { Gal } \beta 1,3-\text { GlcNAc } \\
\mid \alpha 1,4 \\
\text { Fuc }\end{array}$ & Lewis $\mathbf{x}$ (SSEA-1) & $\begin{array}{c}\text { Gal } \beta 1,4-G l c N A c \\
\mid \alpha 1,3 \\
\text { Fuc }\end{array}$ \\
\hline Lewis b & $\begin{array}{ll}\text { Gal } \beta 1,3-G l c N A c \\
\mid \alpha 1,2 & \mid \alpha 1,4 \\
\text { Fuc } & \text { Fuc }\end{array}$ & Lewis y & $\begin{array}{ll}\text { Gal } \beta 1,4-G l c N A c \\
\mid \alpha 1,2 & \mid \alpha 1,3 \\
\text { Fuc } & \text { Fuc }\end{array}$ \\
\hline
\end{tabular}


ticular, we expected that we could detect transfer and expression of functional, cloned cDNAs that determine $\alpha(1,3)$ FT expression by virtue of de novo surface expression of the enzyme's oligosaccharide product (SSEA-1 antigen). Related approaches have been used to detect transfected human genomic DNA restriction fragments that can determine cell surface expression of $H$ (Table 1) (Ernst et al. 1989) and SSEA-1 antigens (Potvin et al. 1990). We adapted the mammalian cDNA expression cloning scheme developed by Seed (Aruffo and Seed 1987; Seed and Aruffo 1987) to implement the system reported here because this would facilitate rescue of the relevant transfected cDNAs.

This approach requires a recipient host cell with specific properties that allow selection of the appropriate cloned cDNA molecules. The host must not express $\alpha(1,3)$ FTs, nor cognate surface $\operatorname{Gal} \beta(1,4)[\operatorname{Fuc} \alpha(1,3)]$ GlcNAc linkages (SSEA-1 structures). However, this host must synthesize the appropriate substrates for surface display of SSEA-1 molecules. These substrates include the nucleotide sugar GDP-fucose, and surface-expressed glycoconjugate molecules that may serve as oligosaccharide acceptors for the transglycosylation reaction. We found that each of these properties was fulfilled by COS-1 cells.

Flow cytometry analysis indicated that COS- 1 cells do not express surface-localized SSEA-1 determinants (Fig. 1, bottom panel). Enzyme analyses performed with COS-1 extracts, using $N$-acetyllactosamine, lactose, or 2 '-fucosyllactose as acceptors, confirmed that absence of SSEA-1 expression was due to a deficiency of $\alpha(1,3)$ FT activity (Table 2 and data not shown). We expected that COS-1 cells would contain substrate levels of GDP-fucose within their Golgi, because, with the exception of certain lectin-resistant mutant cell lines (Reitman et al. 1980|, virtually all mammalian cells synthesize GDP-fucose and translocate it into the Golgi lumen. COS-1 cells also construct surface-expressed glycoconjugates containing unsubstituted polylactosamine moieties that represent potential oligosaccharide acceptors for $\alpha(1,3)$ FT activity determined by a transfected cDNA (Fukuda et al. 1988). In experiments described elsewhere, we confirmed that these substrates are available for use in the construction of surface-expressed, terminal fucose linkages by demonstrating expression of a different terminally linked fucose linkage [H-active, Fuc $\alpha(1,2) \mathrm{Gal}$ linkages; Table 1] on COS-1 cells after transfection with a cloned human cDNA that determines expression of an $\alpha(1,2)$ FT (Larsen et al. 1990a). Therefore, we anticipated that COS-1 cells could construct surface-expressed SSEA-1 molecules after transfection with $\alpha(1,3)$ FT-determining cDNAs.

Isolation of a cloned cDNA that determines expression of an a(1,3)FT and surface-localized SSEA-1 structures

The human A431 cell line has been shown to express cell-surface Lewis blood group a and b structures that represent the products of an $\alpha(1,4) \mathrm{FT}$ (Table 1, Childs et al. 1984). Enzyme assays performed with A431 extracts

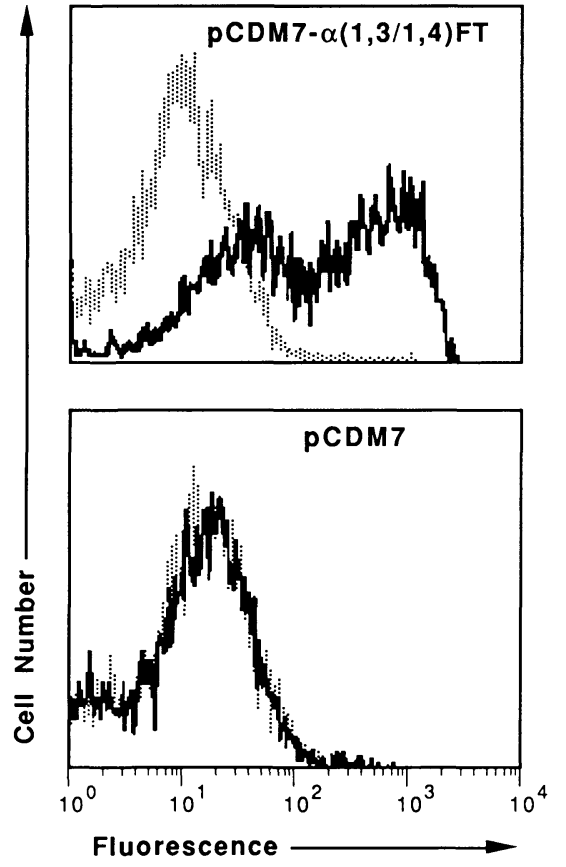

Figure 1. Flow cytometry analysis of cell surface glycoconjugates on transfected COS-1 cells. COS-1 cells were transfected and prepared for flow cytometry analysis as described in Experimental procedures. (Top) Profiles generated by cells transfected with plasmid pCDM7- $\alpha(1,3 / 1,4)$ FT. Transfected cells were stained either with a mouse IgM monoclonal anti-SSEA-1 antibody (solid line), or with a control mouse IgM monoclonal antiLewis b antibody (dotted line), followed by staining with an FITC-conjugated goat anti-mouse IgM antibody. (Bottom) Control profiles generated by cells transfected with the cDNA expression vector $\mathrm{pCDM} 7$, without a cDNA insert. Transfected cells were stained as in top. (Solid lines) Anti-SSEA-1; (stippled lines) control (anti-Lewis b).

confirmed that these cells also express a corresponding $\alpha(1,3)$ FT activity (Table 2$)$. Therefore, a cDNA library was constructed with A431 cell mRNA in the mammalian expression vector $\mathrm{pCDM} 7$ and was transfected into COS-1 cells. The transfected cells were screened (Experimental procedures) by the procedure of Seed (Aruffo and Seed 1987; Seed and Aruffo 1987) using a monoclonal antibody specific for SSEA-1 determinants (Solter and Knowles 1978).

To follow enrichment for an $\alpha(1,3)$ FT-determining cDNA during the selection procedure, an assay was employed in which 2'-fucosyllactose (Table 1) was used as an acceptor substrate. It is believed that this acceptor can discriminate between the Lewis fucosyltransferase and nonallelic human $\alpha(1,3)$ FTs because it is used efficiently by the former enzyme but not by the latter (Johnson et al. 1981). With this assay, we were unable to detect any enzyme activity in COS-1 cells transfected with the A431 cDNA library or in cells transfected with amplified plasmid DNA recovered from the initial selection (Hirt 1, Table 2). Amplified plasmid DNA obtained from the second selection, however, was found to direct a low level of enzyme activity when transfected into 
Table 2. Fucosyltransferase-specific activities in human A431 cells, and in transfected COS-1 cells during library screening and sib selection

\begin{tabular}{lc}
\hline Enzyme source & $\begin{array}{c}\text { Fucose transfer } \\
\text { (pmole/mg protein } \cdot \mathrm{hr} \text { ) }\end{array}$ \\
\hline A431 cells & 51.2 \\
COS-1 cells transfected with: & $\mathrm{ND}$ \\
pCDM7 & $\mathrm{ND}$ \\
A431 cDNA library & $\mathrm{ND}$ \\
Hirt 1 & 3.3 \\
Hirt 2 & 5.3 \\
Hirt 3 & 9.7 \\
pool 2 ( 400 clones) & 510.7 \\
pool 8 (16 clones) & 918.3 \\
pCDM7- $\alpha(1,3 / 1,4) F T$ & \\
\hline
\end{tabular}

Cell extracts, transfections, and enzyme assays, are as described in Experimental procedures. Hirt 1, Hirt 2, and Hirt 3 are amplified plasmid DNAs rescued from the first, second, and third sequential panning procedures, respectively. Pool 2 and pool 8 are plasmid DNAs prepared from groups of transformants generated initially from Hirt 3 transformants. Activity represents transfer to the acceptor $2^{\prime}$-fucosyllactose $[\alpha(1,3)$ FT activity]. (ND) Not detectable.

COS-1 cells (Hirt 2, Table 2). A modest increment in enzyme activity was obtained after a third selection by panning (Hirt 3). At this stage, "sib selection" was employed to identify and isolate a cloned $\alpha(1,3) \mathrm{FT}$ cDNA. Pools of cDNA clones isolated from the third panning selection were tested for their ability to generate $\alpha(1,3)$ FT activity in transfected COS- 1 cells. From these experiments, it was estimated that $\sim 1$ of 500 clones represented a plasmid that determined $\alpha(1,3)$ FT expression. One "active" pool of $\sim 400$ clones (pool 2) was subdivided further and the resulting pools were tested for their ability to generate enzyme activity in transfected cells. One clone [pCDM7- $\alpha(1,3 / 1,4) \mathrm{FT}]$ in an active $16-$ clone pool (pool 8) was found to direct a very high level of expression of the $\alpha(1,3)$ FT (Table 2). Flow cytometry analysis was used to confirm that this plasmid also directs surface expression of SSEA-1 determinants (Fig. 1). COS-1 cells transfected with this plasmid stain brightly with anti-SSEA-1 antibody, but not with a control IgM anti-Lewis b antibody (Fig. 1, upper panel), whereas cells transfected with pCDM7 vector alone exhibit background staining with both antibodies (Fig. 1, lower panel).

Deduced protein sequence of the cloned cDNA predicts a transmembrane topology

The cDNA insert in pCDM7- $\alpha(1,3 / 1,4) \mathrm{FT}$ is $2022 \mathrm{nu}-$ cleotides in length, and consists of a 72-bp 5'-untranslated region, a continuous open reading frame of 1083 bp, and a 3'-untranslated region of $867 \mathrm{bp}$ that is terminated by a poly(A) tail (Fig. 2A). This cloned cDNA hybridizes to a single prominent $2.3-\mathrm{kb}$ transcript in A431 cells (Fig. 3), suggesting that this insert is essentially full-length. The nature of the additional faint $7.5-\mathrm{kb}$ transcript is, at present, undefined. The initiation codon at the beginning of the long open reading frame is embedded within a sequence similar to the Kozak consensus initiation sequence (Kozak 1989), and is preceded by two in-frame stop codons. There is also a single additional ATG upstream from the assigned initiator. This ATG also fits the Kozak consensus sequence, but initiates a very short in-frame sequence. This situation is reminiscent of the upstream initiator ATGs found in other glycosyltransferase transcripts (Weinstein et al. 1987; Shaper et al. 1988; Larsen et al. 1989), suggesting that expression of these glycosyltransferases may be subject to translational control (Kozak 1984). The long open reading frame predicts a 361-amino-acid protein with a molecular mass of 42,069 daltons. Sequence comparisons with the latest DNA and protein sequence data bases (GenBank, Release 60.0 and Protein Identification Resource, Release 21.0) identified no sequences with significant similarity to this sequence, except for a segment within the $3^{\prime}$-untranslated region that is similar to human Alu sequences (Jelinek et al. 1980) (Fig. 2A). The $3^{\prime}$-untranslated region also contains 20 degenerate copies of a 16-nucleotide sequence (Fig. 2A) of unknown functional significance.

Comparisons between the sequence predicted by the insert in pCDM7- $\alpha(1,3 / 1,4) \mathrm{FT}$ and four different cloned mammalian glycosyltransferases (Weinstein et al. 1987; Shaper et al. 1988; Larsen et al. 1989; Yamamoto et al. 1990) revealed no obvious primary sequence similarities. Although these latter enzymes also share no extensive primary sequence similarities, it has been noted that they exhibit an analogous overall structural organization (Paulson and Colley 1989). Specifically, these enzymes are representative of type II transmembrane proteins (Wickner and Lodish 1985), each composed of a short, amino-terminal cytoplasmic domain, a single transmembrane segment, and a larger, carboxy-terminal catalytic domain that ultimately inhabits the Golgi lumen (Larsen et al. 1989; Paulson and Colley 1989). Inspection and hydropathy analysis of the predicted protein sequence (Fig. 2B, Kyte and Doolittle 1982) suggested that this protein maintains a similar structural organization. There is a single hydrophobic segment near the amino terminus (Fig. 2A) that is comprised of 19 amino acids and is flanked by basic residues. This putative signal-anchor sequence would place 327 amino acids within the Golgi lumen, while leaving 15 residues within the cytosolic compartment (Fig. 2A,B).

The protein encoded by $p C D M 7-a(1,3 / 1,4) F T$ is a fucosyltransferase

Expression data presented in Table 2 and Figure 1, and the predicted topological similarity of this sequence to other glycosyltransferases, suggested that this cDNA encodes an $\alpha(1,3)$ FT. Nonetheless, these data are also formally consistent with the possibility that this cDNA sequence instead encodes a molecule that trans-determines $\alpha(1,3)$ FT activity by interaction with an endogenous gene, transcript, or protein. To demonstrate that enzymatic activity is directly associated with this mole- 

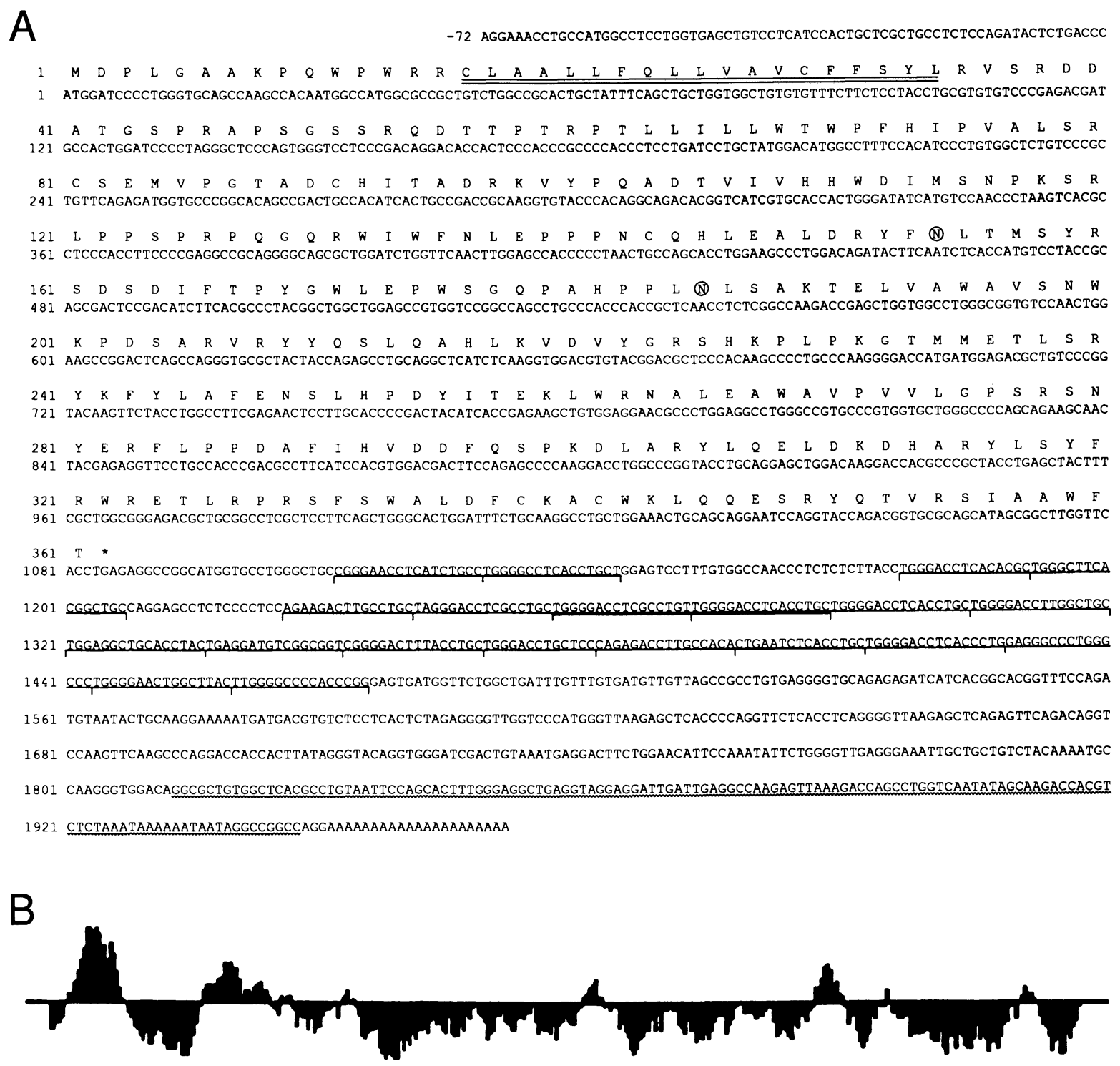

\begin{tabular}{|l|l|l|l|}
\hline C & TM & G \\
\hline
\end{tabular}

Figure 2. DNA and derived protein sequence of the cDNA insert in pCDM7- $\alpha(1,3 / 1,4) \mathrm{FT}$. $(A)$ DNA and derived protein sequence. Predicted amino acid sequence is given in single letter code. The putative transmembrane domain (residues 16-34) is denoted by a double underline. Asparagine residues that represent potential $\mathrm{N}$-glycosylation sites are circled. The repeated sequence motif in the 3 '-untranslated region is denoted by a single underline. The bold underlining is under the two adjacent 16-bp segments that maintain identity to a consensus sequence for this repeat (TGGGGACCTCPuCCTGT). The stippled underlining indicates sequences that are similar to portions of human Alu sequences (Jelinek et al. 1980). (B) Hydropathy plot (Kyte and Doolittle 1982) and proposed domain structure for the predicted polypeptide. Hydrophobic regions are indicated by the shading above the horizontal axis. $(C)$ Cytoplasmic domain; (TM) transmembrane segment; (G) catalytic domain in Golgi lumen.

cule, the putative catalytic domain of the predicted polypeptide was fused to a secreted form of the IgG binding domain of Staphylococcus aureus protein $\mathrm{A}$ in the mammalian expression vector pPROTA (Sanchez-Lopez et al. 1988) (see Experimental procedures) to generate the vector pPROTA- $\alpha(1,3 / 1,4) \mathrm{FT}_{\mathrm{c}}$. Because this fusion protein would lack the putative transmembrane anchoring segment of the fucosyltransferase, we expected it would be synthesized as a secreted molecule that could be affinity-purified on an IgG-containing matrix and subsequently tested for $\alpha(1,3) \mathrm{FT}$ activity. COS- 1 cells transfected with the control vectors PCDM7 or pPROTA generated no detectable cell-associated or released enzyme activity. Conditioned media prepared from COS-1 cells transfected with pPROTA- $\alpha(1,3 / 1,4) \mathrm{FT}_{\mathrm{c}}$ or with pCDM7- $\alpha(1,3 / 1,4 \mid F T$, however, contained significant 


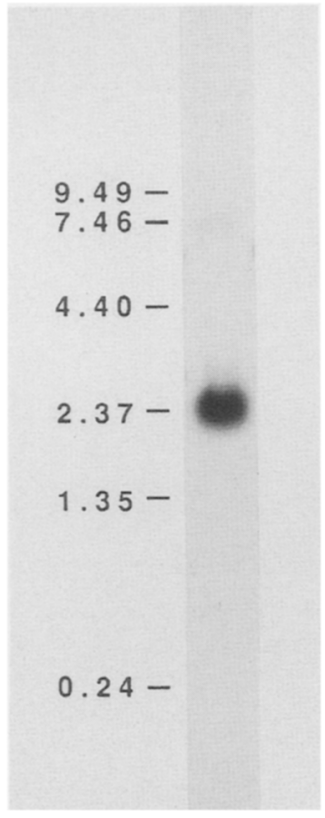

Figure 3. Northern blot analysis of human A431 cells. Total cellular RNA (15 $\mu \mathrm{g})$ prepared from A431 cells was subjected to Northern blot analysis. The blot was probed with a radiolabeled XhoI-XbaI fragment of the insert in pCDM7- $\alpha(1,3 / 1,4) \mathrm{FT}(\mathrm{Ex}-$ perimental procedures). RNA molecular size standards in kilobases are indicated at left.

quantities of $\alpha(1,3)$ FT activity (Table 3). Significantly, virtually $100 \%$ of the released activity generated by pPROTA- $\alpha(1,3 / 1,4) \mathrm{FT}_{\mathrm{c}}$ was specifically retained by the IgG-Sepharose matrix, and $\sim 24 \%$ of this activity could be recovered from the matrix after exhaustive washing.
By contrast, the released activity generated by pCDM7$\alpha(1,3 / 1,4)$ FT did not interact with the affinity adsorbent. These results indicate that the protein encoded by this cloned cDNA encodes a fucosyltransferase and demonstrate that information sufficient to generate $\alpha(1,3) \mathrm{FT}$ activity resides within the enzyme's carboxy-terminal 319 amino acids.

\section{The fucosyltransferase is a glycosylated transmembrane protein}

To confirm the transmembrane topology predicted for the enzyme, fucosyltransferase cRNA was prepared and was subjected to analyses by a series of in vitro translation experiments. The ${ }^{35} \mathrm{~S}$-methionine-labeled primary translation product generated in these experiments migrated with a molecular mass of $\sim 37,500$ daltons (Fig. $4 \mathrm{~A}$, lane 3 ). The discrepancy between this observed molecular mass and the predicted one (42,069 daltons) may be reconciled by the observation that membrane-spanning proteins can migrate in an anomalously rapid manner through SDS-polyacrylamide gels relative to soluble protein molecular weight markers (Mueckler et al. 1985; James et al. 1989). When this radiolabeled protein was generated by in vitro translation in the presence of canine pancreatic microsomes, it migrated with a molecular mass of $\sim 42,000$ daltons (Fig. 4A, lane 4 ). The $\sim 6,000$ dalton increase in molecular mass observed when the translations were performed in the presence of microsomes suggests that two core glycosylation structures are added by microsomal oligosaccharyltransferase (Kornfeld and Kornfeld 1985) to the two potential asparagine-linked glycosylation sites (residues 154 and 185, Fig. 2A) during cotranslational translocation across the

Table 3. Soluble and cell-associated recombinant fucosyltransferase activities

A. Released versus cell-associated fucosyltransferase activity

\begin{tabular}{lcc}
\hline & $\begin{array}{l}\text { Cell-associated } \\
\text { activity (units) }\end{array}$ & $\begin{array}{l}\text { Released } \\
\text { activity (units) }\end{array}$ \\
\hline pCDM7- $\alpha(1,3 / 1,4)$ FT & 580 & $3,000(84 \%$ of total $)$ \\
pPROTA- $\alpha(1,3 / 1,4) \mathrm{FT}_{\mathrm{c}}$ & 440 & $21,740(98 \%$ of total)
\end{tabular}

B. Affinity chromatography of protein A-fucosyltransferase fusion protein

\begin{tabular}{|c|c|c|c|c|c|c|}
\hline \multirow{2}{*}{$\begin{array}{l}\text { Transfected } \\
\text { vector }\end{array}$} & \multicolumn{3}{|c|}{$\begin{array}{l}\text { Sepharose-IgG } \\
\text { [activity (units)] }\end{array}$} & \multicolumn{3}{|c|}{$\begin{array}{c}\text { Sepharose } \\
\text { [activity (units)] }\end{array}$} \\
\hline & applied & flowthrough & $\overline{\text { bound }}$ & applied & flowthrough & bound \\
\hline pCDM7- $\alpha(1,3 / 1,4) \mathrm{FT}$ & 410 & 340 & none & 410 & 360 & none \\
\hline pPROTA- $\alpha(1,3 / 1,4) \mathrm{FT}_{\mathrm{c}}$ & 4,300 & none & 1,030 & 4,300 & 2,080 & none \\
\hline
\end{tabular}

COS- 1 cells were transfected with pCDM7- $\alpha(1,3 / 1,4) \mathrm{FT}$, or with pPROTA- $\alpha(1,3 / 1,4) \mathrm{FT}$. $\mid$ (A) After a 72 -hr expression period, the media were harvested and processed, and cell extracts were prepared and assayed for $\alpha(1,3) \mathrm{FT}$ activity, all as described in Experimental procedures. The entire activity in cell extracts prepared from an entire plate of transfected cells is denoted "Cell-associated activity", whereas the total activity found in the processed media harvested from the same plate is "Released activity". $(B)$ Aliquots of released activity ("applied" activity) were subjected to chromatography on either Sepharose-IgG, or on Sepharose 6B. Fucosyltransferase activity was then determined on the matrix supernatants ("flowthrough" activity) and the washed matrices ("bound" activity), as detailed in Experimental procedures. One enzyme unit $=$ pmole $/ \mathrm{hr}$ transfer of fucose from GDP-fucose to $2^{\prime}$-fucosyllactose $[\alpha(1,3)$ FT activity] under standard assay conditions. 


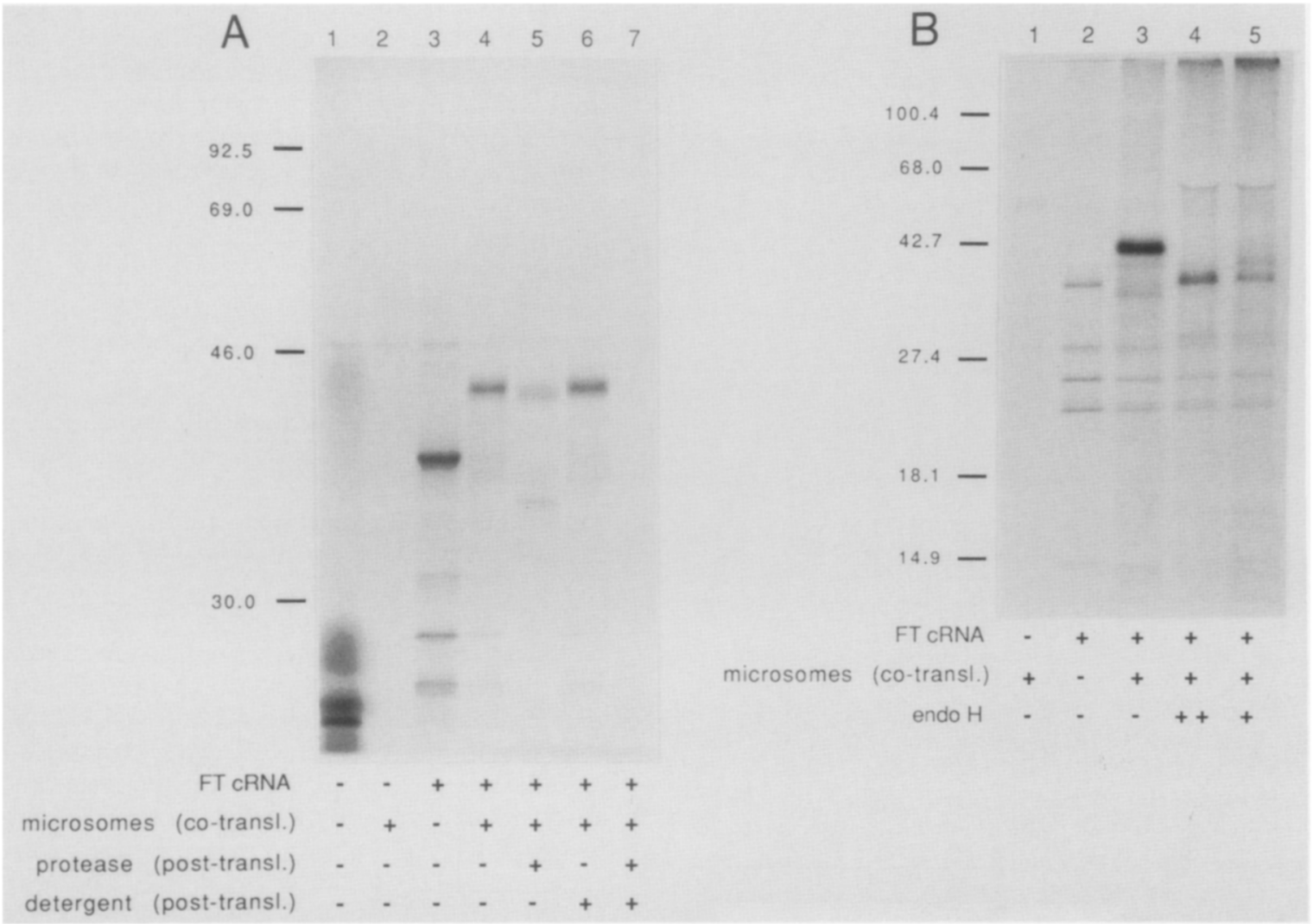

Figure 4. In vitro translation of $\alpha(1,3 / 1,4) \mathrm{FT}$ RNA. $(A)$ Autoradiograph of ${ }^{35} \mathrm{~S}$-methionine-labeled in vitro translation products fractionated by SDS-PAGE. An in vitro-generated RNA transcript complementary to the insert in pCDM7- $\alpha(1,3 / 1,4)$ FT (FT cRNA, see Experimental procedures/ was used to program a rabbit reticulocyte in vitro translation cocktail containing ${ }^{35} \mathrm{~S}$-methionine. Translations were done in the absence (lane 3) or the presence (lanes 4-7) of canine pancreas microsomes. Products generated in the presence of microsomes were subjected to digestion with proteinase $\mathrm{K}$ either before or after detergent-mediated microsome disruption (lanes 5 and 7, respectively). Products generated in the absence of added FT cRNA, and in the absence or presence of microsomes, are shown in lanes 1 and 2, respectively. Lane 6 demonstrates that in the absence of added proteinase $\mathrm{K}$, the product generated in the presence of microsomes remains intact when the microsomes are disrupted by detergent. $(B)$ SDS-PAGE fractionation of ${ }^{35} S$-methionine-labeled in vitro translation products before and after digestion with endoglycosidase $\mathrm{H}$. In vitro translations were performed with FT cRNA as in $(A)$, either in the absence (lane 2), or in the presence (lanes 3-5) of canine pancreatic microsomes. Microsome-associated products were then isolated by ultracentrifugation, as described in Experimental procedures. The products were dissociated from the microsomes and denatured by boiling in the presence of SDS. Material generated by microsomal cotranslation was either analyzed directly (lane 3) or was subjected first to digestion with endoglycosidase $\mathrm{H}$ [10 mU (lane 4); $5 \mathrm{mU}$ (lane 5)]. Material generated in the absence of microsomes (primary translation product) is shown in lane 2. Lane 1 demonstrates microsome-associated products generated in the absence of added FT cRNA.

microsomal membrane. This product also cosedimented with the microsomes (Fig. 4B), suggesting that the protein had become cotranslationally inserted within, or translocated across, the microsomal membrane. When this radiolabeled, microsome-associated protein (Fig. 4B, lane 3) was subjected to limit digestion with endoglycosidase $\mathrm{H}$ (Fig. 4B, lane 4), its molecular mass was reduced to one essentially identical to that of the primary translation product (Fig. 4B, lane 2). Partial endoglycosidase $\mathrm{H}$ digestion generated an additional band of intermediate size (Fig. 4B, lane 5), which likely consists of molecules that contain a single residual core glycosylation unit. These results indicate that the addition of core oligosaccharide structures is responsible for the increase in size of the protein observed in the cotranslation experiments.
These observations indicate that the two potential $\mathrm{N}$ glycosylation sites found within the predicted fucosyltransferase amino acid sequence are glycosylated during translocation across the microsomal membrane.

Additional support for the predicted transmembrane topology of the fucosyltransferase was provided by the results of protease protection experiments. Cotranslation in the presence of microsomes yields a $42-\mathrm{kD}$ polypeptide that is resistant to digestion with protease (Fig. $4 \mathrm{~A}$, lane 5). The protease-digested product migrates slightly faster than the undigested, microsome-associated polypeptide (Fig. 4A, lane 4); this difference is most likely accounted for by removal of some or all of the 15 amino-terminal amino acids predicted to be displayed on the exterior of the microsomes (Fig. 2). Addi- 


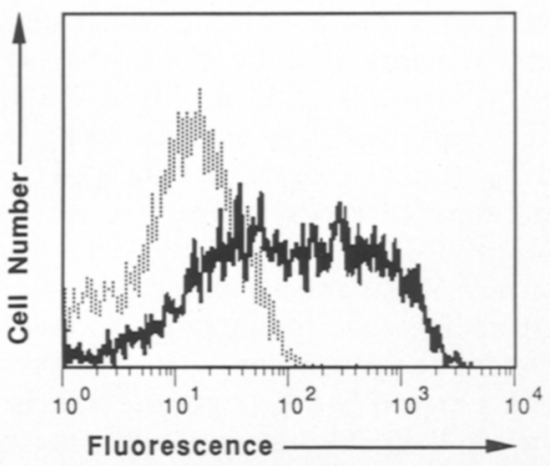

Figure 5. Flow cytometry analysis of surface-expressed Lewis a antigen on transfected COS-1 cells. COS-1 cells were transfected and prepared for flow cytometry analysis as described in Experimental procedures. Profiles were generated by cells transfected with plasmid pCDM7- $\alpha(1,3 / 1,4) \mathrm{FT}$ (solid line) or with the cDNA expression vector pCDM7 without a cDNA insert (dotted line). Transfected cells were stained with a mouse IgM monoclonal anti-Lewis a antibody, followed by staining with an FITC-conjugated goat anti-mouse IgM antibody. (Solid line) pCDM7- $\alpha(1,3 / 1,4) \mathrm{FT}$; (stippled line) pCDM7.

tion of microsomes after translation yielded a proteasesensitive, nonglycosylated radiolabeled product, indicating that membrane insertion of the protein is a cotranslational, but not post-translational, event (data not shown). A small amount of a $\sim 34-\mathrm{kD}$ polypeptide can also be identified in these experiments (Fig. 4A, lane $5)$; the precise nature of this protein is unknown, but it appears in a proteinase $\mathrm{K}$ concentration-dependent manner (data not shown). Therefore, we suspect that it represents a proteolytic fragment of the intact protein generated when the integrity of some microsomal vesicles is disrupted. In aggregate, these experiments indicate that the bulk of this polypeptide can be sequestered within the microsomal lumen by a cotranslational translocation process, ultimately yielding a product that is N-glycosylated. These results are consistent with the type II transmembrane topology predicted by the fucosyltransferase sequence.

\section{The fucosyltransferase can construct two distinct glycosidic linkages}

Plasmid pCDM7- $\alpha(1,3 / 1,4)$ FT was isolated with an enrichment scheme involving an assay for $\alpha(1,3)$ FT activity, using an acceptor substrate (2'-fucosyllactose) thought to be specific for the Lewis fucosyltransferase (Johnson et al. 1981). Because genetic and biochemical studies have indicated that the Lewis fucosyltransferase may also exhibit $\alpha(1,4)$ FT activity (Johnson et al. 1981; Prieels et al. 1981), it was of interest to test the fucosyltransferase encoded by pCDM7- $\alpha(1,3 / 1,4)$ FT for this property.

Flow cytometry analysis of COS-1 cells transfected with pCDM7- $\alpha(1,3 / 1,4) \mathrm{FT}$ and stained with a monoclonal anti-Lewis a antibody indicates that this plasmid can determine surface expression of the Lewis a antigen (Fig. 5; Table 1), that is the product of $\alpha(1,4)$ FT activity.
Likewise, this plasmid can determine surface expression of SSEA-1 molecules on transfected COS-1 cells (Fig. 1). When considered together with the enzymatic data presented in Table 2, these results suggested that this plasmid does indeed encode a "bifunctional" fucosyltransferase. To confirm these observations further, however, we performed a series of biochemical analyses to determine the acceptor specificities of the recombinant enzyme. Extracts of COS-1 cells transfected with pCDM7- $\alpha(1,3 / 1,4) F T$ were tested for their ability to catalyze transglycosylations between GDP- $\left[{ }^{14} \mathrm{C}\right]$ fucose and the type II acceptors lactose and $\mathrm{N}$-acetyllactosamine, or the type I acceptor lacto- $N$-biose I (Table 1). There are only two possible classes of monofucosylated products that can be formed from each of these acceptors by known human fucosyltransferases (Beyer et al. 1982; Sadler 1984). These are $\mathrm{H}$-active products containing a Fuc $\alpha(1,2)$ linkage on the terminal Gal of these molecules (Table 1), or Lewis $\mathrm{x}$ - or Lewis a-active products (Table 1) containing fucose linked in alpha anomeric configuration to the subterminal monosaccharide of these acceptors via either the monosaccharide's C4 hydroxyl (type I acceptor) or its C3 hydroxyl (type II acceptors). Therefore, we fractionated the reaction products with a descending paper chromatography method that could distinguish between the two reaction products possible with each acceptor and could thus allow determination of enzyme specificity.

We found that the type II acceptor lactose was used by the recombinant enzyme to form a radiolabeled compound with the chromatographic mobility $\left(R_{2^{\prime} \text {-fucosyllactose }}=0.88 ;\right.$ Montreuil 1960; Kobata 1972) characteristic of the Lewis $\mathrm{x}$ trisaccharide 3-fucosyllactose (Table 1) and distinct from the other possible product, the type II $\mathrm{H}$ trisaccharide 2 -fucosyllactose. Likewise, the recombinant enzyme in these extracts used $N$-acetyllactosamine to generate a product with a mobility distinct from the $\mathrm{H}$-active trisaccharide 2 '-fucosyl- $N$-acetyllactosamine $\left(\mathrm{R}_{2^{\prime} \text {-fucosyl- } N \text {-acetyllactosamine }}=0.82\right)$, and consistent with its identity as 3 -fucosyl- $N$-acetyllactosamine (Table 1).

Moreover, the radiolabeled product of the type I acceptor lacto- $N$-biose I chromatographed with a mobility distinct from the $\mathrm{H}$-active standard 2 -fucosyllacto- $N$ biose I $\left(\mathbf{R}_{2^{\prime} \text {-fucosyllacto-N-biose I }}=0.90\right)$, and consistent with its identity as the Lewis a trisaccharide 4-fucosyllacto$N$-biose I (Table 1). Identical results were obtained for all three disaccharide acceptors when affinity-purified protein A-fucosyltransferase was used in these experiments. In each case, radiolabeled fucose was quantitatively released from the fucosyltransferase product on digestion with $\alpha$-fucosidase, indicating that the enzyme attaches fucose to these acceptor substrates in an alpha anomeric configuration (See Experimental procedures; data not shown).

In a complementary analysis, type I and type II blood group $\mathrm{H}$ trisaccharides were tested as acceptors for the enzyme encoded by the fucosyltransferase cDNA. Radiolabeled type I and type II $\mathrm{H}$ molecules were prepared by fucosylation of their disaccharide precursors at the 

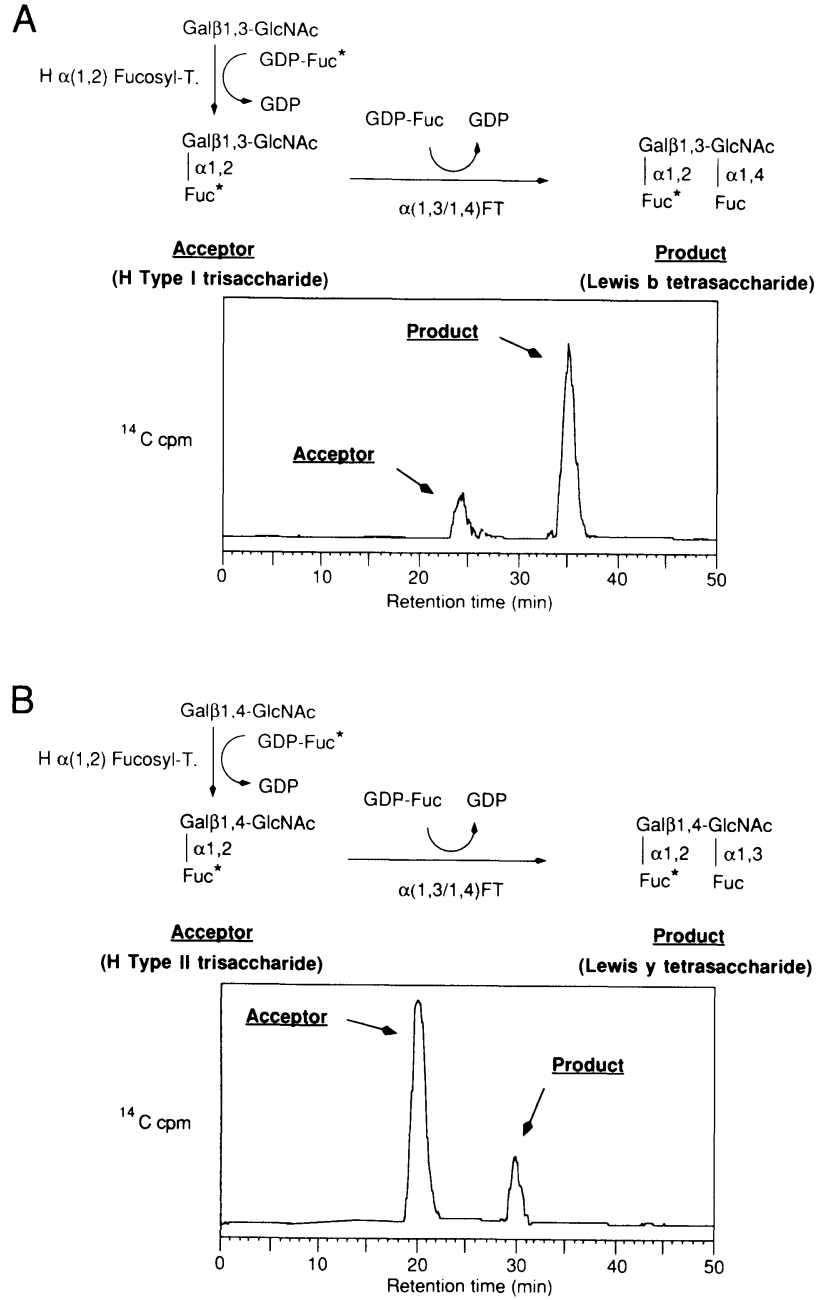

Figure 6. $\alpha(1,3 / 1,4) \mathrm{FT}$ tetrasaccharide product analysis by HPLC. $(A)$ Utilization of $\mathrm{H}$ type I trisaccharide. Radiolabeled $\mathrm{H}$ type I trisaccharide acceptor was prepared with the type I disaccharide precursor lacto- $N$-biose I (Table 1), GDP- $\left[{ }^{14} \mathrm{C}\right]$ fucose $\left(\right.$ GDP-Fuc ${ }^{*}$ ), and $\mathrm{H}$ blood group $\alpha(1,2)$ fucosyltransferase $[\mathrm{H} \alpha(1,2)$ Fucosyl-T.] (see Experimental procedures), as diagrammed schematically above at left. This was then incubated with affinity-purified protein A- $\alpha(1,3 / 1,4) \mathrm{FT}$, and nonradioactive GDP-fucose, in a reaction depicted schematically above the boxed area that displays an HPLC analysis (Mellis and Baenziger 1981) of the reaction products. (B) Utilization of $\mathrm{H}$ type II trisaccharide. Radiolabeled $\mathrm{H}$ type II trisaccharide acceptor was prepared as described in $(A)$, by use of the type II precursor $\mathrm{N}$-acetyllactosamine (see Experimental procedures), as diagrammed schematically above at left. This was then incubated with affinity-purified protein A- $\alpha(1,3 / 1,4) \mathrm{FT}$, and nonradioactive GDP-fucose, as depicted schematically above the HPLC analysis of the products of this reaction. The early peak on each HPLC profile, that is identified as Acceptor, elutes with a retention time identical to that of unreacted acceptor /data not shown); this residual, unreacted acceptor is incompletely converted to product presumably because the concentration of the radiolabeled acceptor in these experiments is submicromolar and thus well below the millimolar $K_{m}$ range described for these and other oligosaccharide acceptors (Prieels et al. 1981). Likewise, the relative efficiencies of percent conversion of each acceptor to product do not necessarily reflect their true affinities for the enzyme.
C2 hydroxyl of their terminal galactose residues by use of cell extracts containing the blood group $\mathrm{H} \alpha(1,2) \mathrm{FT}$ and GDP- $\left[{ }^{14} \mathrm{C}\right]$ fucose (Fig. 6A,B). These HPLC-purified radiolabeled type I and type II $\mathrm{H}$ acceptors were then each used in reactions containing unlabeled GDP-fucose and affinity-purified fucosyltransferase activity generated by pPROTA- $\alpha(1,3 / 1,4) \mathrm{FT}_{\mathrm{c}}$. Amine-adsorption HPLC analysis (Mellis and Baenziger 1981) of these reactions identified new radiolabeled compounds with elution characteristics consistent with those predicted for the Lewis b tetrasaccharide (Fig. 6A), and the Lewis $y$ tetrasaccharide (Fig. 6B), generated with the type I and type II acceptors, respectively. Virtually identical results were obtained with extracts prepared from COS-1 cells transfected with pCDM7- $\alpha(1,3 / 1,4)$ FT (data not shown). Together, these analyses imply that the fucosyltransferase encoded by pCDM7- $\alpha(1,3 / 1,4) \mathrm{FT}$ is able to construct a Fuc $\alpha(1,3)$-glycosidic linkage on the subterminal Glc or GlcNAc of type II acceptors and a Fuc $\alpha(1,4)$-glycosidic linkage on the subterminal GlcNAc of type I acceptors, and that this is qualitatively independent of the presence of terminal Fuc $\alpha(1,2)$ moieties on the terminal galactose of these acceptors. These properties mirror those reported for the fucosyltransferase activities determined by human Lewis blood group locus (Johnson et al. 1981; Prieels et al. 1981) and confirm that a single fucosyltransferase can catalyze the formation of two distinct glycosidic linkages.

The fucosyltransferase cDNA identifies human genomic sequences syntenic to the human Lewis blood group locus

Genetic data indicate that the human Lewis blood group is determined by a locus on chromosome 19 (Le Beau et al. 1989). Therefore, the fucosyltransferase cDNA was used for Southern blot analysis of a pair of humanmouse somatic cell hybrids that differ only by the presence or absence of human chromosome 19 (Miller et al. 1974). The results indicate that at high stringency, the fucosyltransferase cDNA identifies cross-hybridizing sequences located on chromosome 19 (Fig. 7). Taken together with the enzymatic analyses, these data strongly suggest that this cloned cDNA represents the product of the human Lewis blood group locus.

\section{Discussion}

In this paper, we describe the isolation and analysis of a human fucosyltransferase cDNA with an approach that does not require antibodies or sequence information derived from the purified protein, but instead relies on reagents that detect its surface-localized oligosaccharide product and a specific enzymatic assay. Most glycosyltransferases have been identified and characterized by their enzymatic activity, and many lectins and antibodies are available that specifically recognize the products of these enzymes (Liener et al. 1986). Moreover, procedures have been described that allow the generation of mutant animal cell lines with specific glycosylation defects (Stanley 1984) suitable for use as trans- 


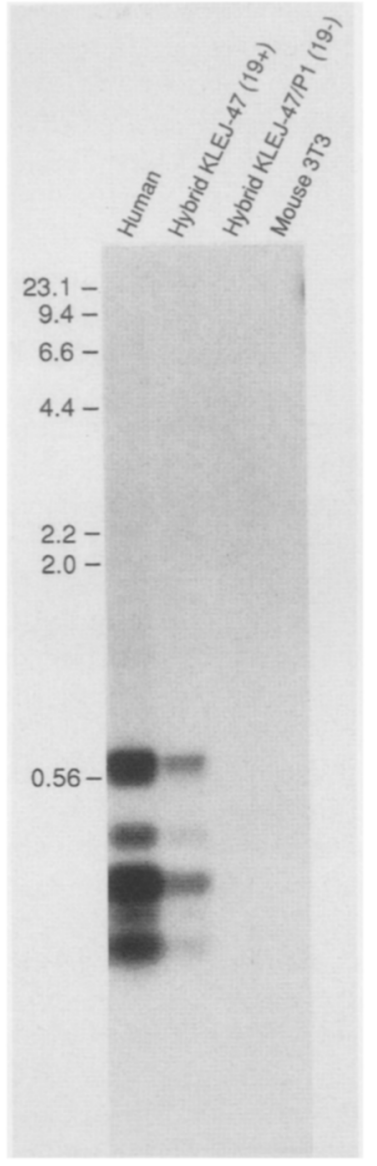

Figure 7. Southern blot analysis of somatic cell hybrids discordant for human chromosome 19. Southern blot analysis was done on genomic DNA prepared from human peripheral blood leukocytes (Human), from a somatic cell hybrid containing several human chromosomes including 19 (KLEJ-47; Miller et al. 1974), from a derivative of KLEJ-47 selected for loss of human chromosome 19 but with a human chromosome complement otherwise identical to that of KLEJ-47 (KLEJ-47/P1; Miller et al. 1974), and from the mouse hybrid parent (3T3). DNA was digested with $M s p I$. The blot was probed at high stringency with an $X h o I-X b a I$ restriction fragment isolated from the insert in pCDM7- $\alpha(1,3 / 1,4) \mathrm{FT}$ (see Experimental procedures). Relative mobilities of molecular size markers are indicated at left in kilobases. The hybridization intensities of the bands in the KLEJ-47 lane are less than those in the human lane because only $\sim 61 \%$ of the cells in the KLEJ-47 population retain chromosome 19 (Miller et al. 1974).

fection hosts, which can supplement existing animal cell lines, like COS-1 cells. Therefore, we expect that this approach and related ones (Ernst et al. 1989; Kumar and Stanley 1989; Larsen et al. 1989; Rajan et al. 1989; Ripka et al. 1989; Potvin et al. 1990) may be generally useful for the isolation of other glycosyltransferase cDNAs.

Sequence analysis of this fucosyltransferase cDNA indicates that it encodes a $\sim 42-\mathrm{kD}$ protein, with catalytic properties identical to the Lewis fucosyltransferase previously purified $>500,000$-fold from human milk
(Prieels et al. 1981). The latter protein was assigned a molecular mass of 51-53 kD. Post-translational modification, including $\mathrm{N}$ - and O-linked glycosylation, probably accounts for the larger apparent size of the milk-derived protein. As described for other mammalian glycosyltransferases (Weinstein et al. 1987; D'Agostaro et al. 1989|, the soluble enzyme found in milk presumably represents a fragment of the intact protein comprised of the catalytic domain separated from its transmembrane tether by a proteolytic event that occurs during its purification and/or biosynthesis (Weinstein et al. 1987). In this regard, it is interesting to note that the intact $\alpha(1,3 /$ $1,4 \mid$ FT cDNA directs the release of soluble $\alpha(1,3 / 1,4)$ FT activity into the culture media of transfected COS-1 cells (Table 3). Although the structure(s) of the released and catalytically active polypeptide(s) remains to be determined, this observation suggests that COS-1 cells maintain mechanisms that mimic the biosynthetic processes that normally generate secreted glycosyltransferases.

In individuals who express Lewis blood group antigens, the corresponding $\alpha(1,4) \mathrm{FT}$ activity can be found in a variety of secretions and tissues (Watkins 1980; Johnson et al. 1981; Prieels et al. 1981). By contrast, roughly $10 \%$ of Caucasian individuals do not express Lewis antigens (Watkins 1980) or detectable $\alpha(1,4)$ FT activity (Johnson et al. 1981). When purified from pooled human milk, the Lewis $\alpha(1,4) \mathrm{FT}$ activity was found to have copurified with an $N$-acetylglucosaminide $\alpha(1,3 \mid \mathrm{FT}$ activity (Prieels et al. 1981). Biochemical analyses performed on this purified enzyme were consistent with the unprecedented possibility that it represented a single protein capable of catalyzing two distinct transglycosylations, presumably without the assistance of a "modifier" protein like $\alpha$-lactalbumin (Beyer et al. 1982). Lewis-negative individuals would thus presumably be homozygous for null $\alpha(1,3 / 1,4)$ FT allele(s). Because these analyses were performed on purified enzyme prepared from many individuals, however, these data were also consistent with the possibility that the two enzyme activities actually represented distinct copurifying polypeptides. If the latter circumstance were true, allelic variation within the Lewis locus could generate either an $\alpha(1,4) \mathrm{FT}$ activity (Lewis-positive), or an $\alpha(1,3) \mathrm{FT}$ activity, which in the homozygous state would yield a Lewis-negative phenotype.

In a complementary series of experiments, however, Watkins and colleagues (Johnson et al. 1981) demonstrated that the Lewis-determined fucosyltransferase activity could be physically separated from an $\alpha(1,3)$ FT activity found in virtually all individuals. Their results also showed that the latter enzyme differs from the Lewis enzyme in that is does not exhibit $\alpha(1,4) \mathrm{FT}$ activity and cannot transfer fucose to the $\mathrm{C}-3$ position of glucose. Taken together, these data indicated that the Lewis $\alpha(1,3 / 1,4)$ FT and the ubiquitous $\alpha(1,3)$ FT represented the products of different genes and supported the notion that Lewis-negative individuals maintain two null alleles at a locus determining expression of a bifunctional fucosyltransferase. Data presented in this 
paper have validated the concept that a single glycosyltransferase can function to catalyze multiple distinct transglycosylation reactions. Although it remains to be demonstrated by formal linkage analysis that the cloned cDNA described here represents the product of the Lewis locus, we nonetheless believe that the catalytic properties of the enzyme it encodes, and its chromosomal localization, provide very strong evidence for this assignment. Tissue-specific expression studies, and structural and functional analyses of alleles isolated from Lewis-negative individuals should also contribute to a better understanding of this gene.

Previous comparisons made between the sequences of several other cloned glycosyltransferases (Weinstein et al. 1987; Joziasse et al. 1989; Larsen et al. 1989; Yamamoto et al. 1990) indicated that each maintains a type II transmembrane topology, but that with one possible exception (Joziasse et al. 1989), there exists no substantial primary sequence similarity between them. These observations were somewhat surprising at the time because pairs of these enzymes share identical acceptor or nucleotide sugar substrate requirements. Consistent with these previous observations, the predicted primary sequence of the enzyme described here is not similar to two other published glycosyltransferases that also use the acceptor substrate $N$-acetyllactosamine $[\alpha(2,6)$ sialyltransferase, Weinstein et al. 1987; $\alpha(1,3)$ galactosyltransferase, Joziasse et al. 1989; $\alpha(1,3)$ galactosyltransferase, Larsen et al. 1989]. Thus, it appears that these enzymes have not evolved by simple juxtaposition of generic domains that determine oligosaccharide acceptor specificity with other modules that determine nucleotidesugar requirements. In this context, we have noted that the primary sequence predicted for the $\alpha(1,3 / 1,4)$ FT sequence described here is not at all similar to the cloned blood group $\mathrm{H} \alpha(1,2)$ FT (Rajan et al. 1989; Larsen et al. 1990a). These observations suggest that even enzymes with identical nucleotide sugar substrate and acceptor requirements may maintain distinct primary sequences.

Finally, it is worth noting that polymorphism in the expression of glycosyltransferases occurs in many organisms, including man (Watkins 1980), mouse (Ponder et al. 1985), and some plants (Brederode and Nigtevecht 1974). It is also interesting to note that many humans are amorphic for one or more oligosaccharide blood group antigens and are presumably homozygous for null alleles at the glycosyltransferase loci that determine their biosynthesis (Watkins 1980; Sadler 1984). Moreover, species-specific glycosylation patterns exist that in at least one instance have apparently evolved via conversion of a once functional glycosyltransferase gene into a pseudogene (Larsen et al. 1990b). These observations raise the question as to whether the specific oligosaccharide linkages these enzymes construct have essential functions.

It may be possible, for example, that many oligosaccharide linkages have been rendered biologically neutral by evolutionary mechanisms. Or perhaps these enzymes have evolved other functions, like adhesion (Roseman 1970; Rauvala et al. 1983; Shur 1983; Bayna et al. 1988), or structure (like the enzymes that also function as lens crystallins; for review, see de Jong et al. 1989), that are independent of now nonessential catalytic properties. Alternatively, it can be speculated that the catalytic activity of these enzymes is essential and that their oligosaccharide products maintain critical roles during development but are nonessential in the adult organism. Thus, although nonexpression during embryogenesis may be lethal, it is possible that allelic variation in adult expression patterns may be tolerated. This scenario predicts that null glycosylation phenotypes may arise from glycosyltransferase genes with functionally intact structural regions and stage-specific regulatory sequences, but with mutations elsewhere that prevent expression after the last developmental stage in which the cognate oligosaccharide linkage has an essential role. Another possibility is suggested by the functional redundancy inherent in the existence of multiple distinct glycosyltransferases capable of constructing identical oligosaccharide linkages (Watkins 1980; Beyer et al. 1982; Sadler 1984). This redundancy may be sufficiently extensive to permit null alleles at one or more of these loci without an obvious detrimental phenotype. The presence of alternative chain-terminating monosaccharides determined by allelic glycosyltransferases (Watkins 1980; Beyer et al. 1982; Sadler 1984) suggests that such functional redundancy might also be served by any one of several distinct monosaccharides in linkage to a specific subterminal monosaccharide and catalyzed by any of several glycosyltransferases. Insight into some of these issues may be accomplished by genetic approaches involving the use of transgenic animals. Investigation of oligosaccharide function via this avenue may be facilitated by processes described here and elsewhere (Larsen et al. 1989; Rajan et al. 1989; Potvin et al. 1990) that have the potential to provide additional cloned gene segments that determine glycoconjugate expression.

\section{Experimental procedures}

\section{cDNA library construction}

A cDNA library was prepared from poly $(A)+$ RNA isolated from human A431 cells, using the procedure of Seed (Aruffo and Seed 1987; Seed and Aruffo 1987) and the mammalian expression vector pCDM7. pCDM7 lacks polyoma sequences present in the vector pCDM8 (Seed 1987), but is otherwise virtually identical (B. Seed, pers. comm.). The library contained $2.6 \times 10^{6}$ independent recombinants.

\section{Cell lines}

Mouse 3T3-human hybrid cell lines KLEJ-47 and KLEJ-47/P-1 (Miller et al. 1974) were obtained from Dr. Howard Green (Harvard University, Boston). Mouse 3T3 cells were from Dr. Vishva Dixit (University of Michigan, Ann Arbor). The origins of all other cell lines and conditions for cell growth are as described previously (Miller et al. 1974; Ernst et al. 1989; Rajan et al. 1989|.

Preparation of panning dishes

Panning dishes were prepared (Wysocki and Sato 1978) as de- 
scribed previously (Ernst et al. 1989; Larsen et al. 1989), by coating them first with goat anti-mouse IgM, and then with monoclonal IgM anti-SSEA-1 antibody (Solter and Knowles 1978 ) as ascites diluted $1: 1000$, which were generously provided by $D$. Solter.

\section{cDNA library screening}

The A431 library was screened as described previously (Larsen et al. 1989). Plasmid DNA was rescued (Hirt 1967) from transfected COS-1 cells adherent to panning dishes and introduced into the bacterial host MC1061/P3 by transformation (Seed and Aruffo 1987). Transformants were grown to saturation in liquid culture under antibiotic selection, aliquots were removed for frozen storage, and the remainder of the culture was used to prepare plasmid DNA. A portion of this plasmid DNA was used for subsequent enrichment by transfection and immunoselection on anti-SSEA-1 panning dishes.

\section{Flow cytometry analysis}

Transfected COS-1 cells were stained (Ernst et al. 1989) with the mouse IgM anti-SSEA-1 monoclonal antibody $(1: 1000 \mathrm{di}-$ lution of ascites), mouse monoclonal IgM anti-Lewis b monoclonal antibody (Chembiomed, Ltd., Edmonton, Alberta; 10 $\mu \mathrm{g} / \mathrm{ml}$ ), or mouse monoclonal IgM anti-Lewis a antibody (Chembiomed Ltd., Edmonton, Alberta; $10 \mu \mathrm{g} / \mathrm{ml}$ ). Cells were then stained with fluorescein-conjugated goat anti-mouse IgM (Sigma; $40 \mu \mathrm{g} / \mathrm{ml}$ ) and subjected to analysis by flow cytometry on a FACScan (Becton Dickinson, Mountain View, CA), as described previously (Ernst et al. 1989; Larsen et al. 1989). Cell staining was measured in arbitrary units as the log of fluorescent intensity and displayed on a 4 decade scale.

\section{Northern and Southern blotting}

A431 cell RNA was subjected to Northern blot analysis as described previously (Larsen et al. 1989). The probe consisted of a $1.7-\mathrm{kb} X \mathrm{XhoI}-\mathrm{XbaI}$ fragment isolated from the $5^{\prime}$ end of the cDNA insert in plasmid pCDM7- $\alpha(1,3 / 1,4)$ FT. This fragment does not contain the portion of this cDNA that exhibits sequence similarity to human Alu sequences (Fig. 2). This probe was labeled by nick-translation (Rigby et al. 1977) with $\left[\alpha^{-32} \mathrm{P}\right] \mathrm{dCTP}$ to a specific activity of $6 \times 10^{8} \mathrm{cpm} / \mu \mathrm{g}$.

Genomic DNA was prepared and subjected to Southern blotting as described previously (Ernst et al. 1989; Larsen et al. $1990 \mathrm{~b})$. Blots were subjected to a final wash for $30 \mathrm{~min}$ at $65^{\circ} \mathrm{C}$ in $0.1 \times$ SSC, $0.5 \%$ SDS. The probe used was identical to the one used for Northern blot analysis except that it was labeled with the random priming method (Feinberg and Vogelstein 1983).

\section{Sequencing}

The cDNA insert in plasmid pCDM7- $\alpha(1,3 / 1,4) \mathrm{FT}$ was sequenced by the chain-termination method (Sanger et al. 1977) using a double stranded plasmid DNA template and commercial reagents (Pharmacia). Both strands were sequenced using 17-mer or 19-mer oligonucleotide probes synthesized according to the sequence of the cDNA insert. The DNA sequence was assembled and analyzed using the Beckman Microgenie package and the Sequence Analysis Software Package of the University of Wisconsin Genetics Computer Group (Devereaux et al. 1984).

\section{In vitro transcription/translation}

Plasmid pCDM7- $\alpha(1,3 / 1,4)$ FT DNA was linearized downstream from the cloned cDNA insert by digestion with NotI. Capped RNA transcripts were then generated from this linearized template using a T7 polymerase promoter-based in vitro transcription kit (Pharmacia). Transcripts initiate from the T7 promoter proximal to the cDNA cloning site in pCDM7 (Seed 1987). RNA transcripts produced in vitro were used to program a rabbit reticulocyte lysate in vitro translation system (Promega), in the presence of ${ }^{35} \mathrm{~S}$-methionine (Amersham), according to the manufacturer's instructions. Membrane-associated radiolabeled in vitro translation products, generated in the presence of canine pancreatic microsomal membranes (Promega) (cotranslation) or generated prior to the addition of microsomes (posttranslational microsome addition), were isolated from the bulk of the soluble reaction components by centrifugation through a sucrose cushion $[0.5 \mathrm{M}$ sucrose, $10 \mathrm{~mm}$ Tris $(\mathrm{pH} 7.4)$, and 150 $\mathrm{mM} \mathrm{NaCl}$; at 170,000g for $60 \mathrm{~min}$; (Walter and Blobel 1983). For endoglycosidase $\mathrm{H}$ digestions (Speiss and Lodish 1986), pellets containing microsome-associated radiolabeled products were first resuspended in $50 \mathrm{~mm}$ sodium citrate ( $\mathrm{pH} 5.5)$, were made $0.2 \%$ in SDS, and were heated to $100^{\circ} \mathrm{C}$ for $4 \mathrm{~min}$. Aliquots of this material were then diluted with an equal volume of water and subjected to digestion with either $10 \mathrm{mU}$ or $5 \mathrm{mU}$ of endoglycosidase $\mathrm{H}$ (Boehringer-Mannheim) for $20 \mathrm{hr}$ at $37^{\circ} \mathrm{C}$ in the presence of $0.1 \%$ bovine serum albumin, $0.5 \%$ Triton $\mathrm{X}-100,0.5 \mathrm{mM}$ phenylmethylsulfonyl fluoride, $40 \mu \mathrm{g} / \mathrm{ml} \mathrm{Bes-}$ tatin, $10 \mu \mathrm{g} / \mathrm{ml} \alpha_{2}$ macroglobulin, and $30 \mu \mathrm{g} / \mathrm{ml}$ of E-64. Alternatively, the pellets were resuspended in ice cold in vitro translation buffer containing $5 \mathrm{mM} \mathrm{CaCl}_{2}$ and were subjected to incubation with $150 \mu \mathrm{g} / \mathrm{ml}$ proteinase $\mathrm{K}$, on ice for $1 \mathrm{hr}$, in the presence or absence of $1 \%$ Triton X-100. The various radiolabeled in vitro translation products were then denatured and reduced by heating to $100^{\circ} \mathrm{C}$ for $4 \mathrm{~min}$ in $62.5 \mathrm{~mm}$ Tris $(\mathrm{pH} 6.8)$, $100 \mathrm{~mm}$ dithiothreitol, $2 \%$ SDS, $10 \%$ glycerol, and $0.02 \%$ bromphenol blue. Samples were then fractionated through SDS-polyacrylamide gels, and the gels were subjected to autoradiography.

\section{Fucosyltransferase assays}

Cultured cells were washed in PBS, harvested by scraping with a rubber policeman, washed again in PBS, and pelleted by centrifugation. Cell extracts were prepared by resuspending cell pellets in $1 \%$ Triton $\mathrm{X}-100$ such that the final protein concentration in the extracts was $\sim 5 \mathrm{mg} / \mathrm{ml}$ (BCA method, Pierce Chemical Co.).

Fucosyltransferase assays were performed in $50 \mathrm{mM}$ MOPS (pH 6.5), $25 \mathrm{mM} \mathrm{MnCl}_{2}, 10 \mathrm{~mm}$ L-fucose, $5 \mathrm{mM} \mathrm{ATP,} 3 \mu \mathrm{M}$ GDP-[ ${ }^{14} \mathrm{C}$ ) fucose (sp. act. of $600,000 \mathrm{cpm} / \mathrm{nmole}$; $35,000 \mathrm{cpm}$ per assay), $2.5 \mathrm{~mm}$ acceptor [e.g., 2'-fucosyllactose (Sigma or Biocarb), $N$-acetyllactosamine (Sigma), lactose (Sigma), or lacto$N$-biose I (Sigma)], and up to $10 \mu \mathrm{l}$ of cell extract, in a final volume of $20 \mu \mathrm{l}$. When determining $\alpha(1,3) \mathrm{FT}$ specific activities achieved during the sib selection process and in the analysis of the protein A-fucosyltransferase fusion protein experiments (Table 3), the amount of added cell extract and incubation times were adjusted to yield (linear) reaction rates reflecting accurate specific activities (Rajan et al. 1989). Reactions were incubated at $37^{\circ} \mathrm{C}$ for 2 or $6 \mathrm{hr}$, and then terminated by the addition of 20 $\mu \mathrm{l}$ of ethanol, followed by dilution with $500 \mu \mathrm{l}$ of $\mathrm{H}_{2} \mathrm{O}$. The terminated, diluted reactions were then centrifuged at $15,000 \mathrm{~g}$ for $5 \mathrm{~min}$. Fifty microliters of each reaction supernatant was counted to determine total radioactivity, and $200 \mu$ l of each was fractionated by Dowex-1 chromatography (Rajan et al. 1989). The neutral radiolabeled material eluting from the column was then counted directly as a measure of product formation. Enzyme specific activity is defined as picomole of fucose trans- 
ferred from GDP-fucose to acceptor per milligram of cell extract protein per hour. Neutral products were also analyzed further as described below by descending paper chromatography and by HPLC to confirm their identity. Parallel reactions were done in the absence of added acceptor to allow correction for transfer to endogenous acceptor molecules and for substrate and product hydrolysis (Rajan et al. 1989). These control experiments indicated that less than $2.6 \%$ of the radioactivity of GDP- $\left[{ }^{14} \mathrm{C}\right]$ fucose was found as a neutral product in the absence of added acceptor and that virtually all of this material represented $\left[{ }^{14} \mathrm{C}\right]$ fucose.

In instances where radiolabeled, $\mathrm{H}$ type $\mathrm{I}$ and $\mathrm{H}$ type II molecules were used as acceptors, nonradiolabeled GDP-fucose (Rajan et al. 1989) was included instead of GDP-[14C]fucose, and reactions were allowed to proceed for $16 \mathrm{hr}$. Residual unreacted neutral radiolabeled acceptor substrate and neutral radiolabeled product were isolated by Dowex-1 chromatography and then analyzed by HPLC.

\section{Preparation of radiolabeled $H$ type I and H type II acceptors}

Cell extracts containing a human $\alpha(1,2)$ FT activity were used to synthesize radiolabeled $\mathrm{H}$ type I or $\mathrm{H}$ type II acceptor molecules. The cell extracts were prepared from mHl-12 cells, a mouse L cell transfectant containing a human DNA segment that encodes a human $\alpha(1,2) \mathrm{FT}$ (Ernst et al. 1989; Rajan et al. 1989 ; J.B. Lowe, unpubl.). These extracts contained no detectable $\alpha(1,3)$ FT activity or $\alpha(1,4)$ FT activity (R.P. Nair and J.B. Lowe, unpubl.). Lacto- $N$-biose I (20 mM) or $N$-acetyllactosamine (20 mM) was incubated with $100 \mu \mathrm{g}$ of $\mathrm{mHl}-12$ extract protein in $40 \mu \mathrm{l}$ of $25 \mathrm{~mm}$ sodium cacodylate $(\mathrm{pH} 6.2)$ containing $3 \mu \mathrm{M}$ GDP- $\left[{ }^{14} \mathrm{C}\right]$ fucose, for $16 \mathrm{hr}$ at $37^{\circ} \mathrm{C}$. Reactions were terminated by the addition of $40 \mu \mathrm{l}$ of ethanol followed by dilution with $200 \mu \mathrm{l}$ of water. Precipitated protein was removed by centrifugation at $12,000 \mathrm{~g}$ for $5 \mathrm{~min}$, and the neutral radiolabeled reaction products in the supernatant were isolated by Dowex-1 chromatography. The $\mathrm{H}$ type I trisaccharide molecules (lacto- $N$-biose I reaction) or $\mathrm{H}$ type II trisaccharide molecules ( $N$-acetyllactosamine reaction) comprising the majority of the respective neutral radiolabeled materials were then purified by HPLC as described below.

\section{Product analysis by HPLC and descending paper chromatography}

Neutral radiolabeled reaction products generated by affinity-purified protein A-fucosyltransferase fusion protein, or by pCDM7- $\alpha(1,3 / 1,4) \mathrm{FT}$-programmed COS-1 extracts, type I or type II disaccharide acceptors, and GDP- $\left[{ }^{14} \mathrm{C}\right]$ fucose (see above, fucosyltransferase assays) were fractionated by descending paper chromatography (Montreuil 1960; Kobata 1972) or by HPLC (Mellis and Baenziger 1981) to determine their structures. Samples analyzed by HPLC were dissolved in $70 \%$ acetonitrile and applied to a Dynamax 60A (primary amine column, Rainin Instruments, $4.14 \mathrm{~mm} \times 25 \mathrm{~cm}$ ) equilibrated in acetonitrile/water $(70: 30)$. Compounds were eluted with a linear gradient of acetonitrile/water $(70: 30$ to $40: 60)$ in $1 \mathrm{hr}$ at a flow rate of $1 \mathrm{ml} / \mathrm{min}$. The eluant was monitored with a Beckman Instruments on-line radioisotope detector.

Samples analyzed by descending paper chromatography were dissolved in water and fractionated through Whatman No. 40 in phenol/isopropanol/formic acid/water $(85: 5: 10: 100$, lower layer) (Montreuil 1960; Kobata 1972). After chromatography (40 $\mathrm{hr}$ for type II acceptors, or $48 \mathrm{hr}$ for lacto- $N$-biose I), air-dried chromatograms were cut into $1-\mathrm{cm}$ strips and the radiolabeled compounds were eluted into $2 \mathrm{ml}$ of water. The radioactivity in each eluate was determined by scintillation counting after mixing with $10 \mathrm{ml}$ of scintillation cocktail. HPLC-purified ${ }^{14} \mathrm{C}$ labeled type I and type II $\mathrm{H}$-active trisaccharide standards were prepared as described above for the preparation of ${ }^{14} \mathrm{C}$-labeled type I and type II $\mathrm{H}$-active acceptor trisaccharides.

\section{a-L-Fucosidase digestion}

Neutral, HPLC-purified, radiolabeled fucosyltransferase products were subjected to $\alpha$-L-fucosidase digestion to confirm the alpha anomeric configuration of the attached fucose. 3 - $\left[{ }^{14} \mathrm{C}\right]$ fucosyl- $N$-acetyllactosamine, $\quad 3$ - $\left[{ }^{14} \mathrm{C}\right]$ fucosyl-2'-fucosyllactose, 3-[14 C]fucosyllactose, and $4-\left[{ }^{14} \mathrm{C}\right]$ fucosyllacto- $N$-biose I were purified by amine adsorption HPLC as described above, and aliquots of each $(10,000-20,000 \mathrm{cpm})$ were digested with $100 \mathrm{mU}$ of $\alpha$-L-fucosidase (Boehringer-Mannheim) in $70 \mu \mathrm{l}$ of $100 \mathrm{~mm} \mathrm{Na}$ citrate $(\mathrm{pH} 5.5)$, at $37^{\circ} \mathrm{C}$ for $22 \mathrm{hr}$. The reactions were desalted by Dowex column chromatography and subjected to HPLC analysis under conditions described above. The products of the digestion were identified by comparison to parallel separations of $\mathrm{L}-\left[{ }^{14} \mathrm{C}\right]$ fucose and $\left[{ }^{14} \mathrm{C}\right]$ fucose-labeled acceptors. In each case, quantitative release of $\mathrm{L}-\left[{ }^{14} \mathrm{C}\right]$ fucose was achieved by $\alpha$-L-fucosidase digestion.

\section{pPROTA-a $(1,3 / 1,4) F T_{c}$ construction and analysis}

A 1344-bp SmaI-BamI segment of the cDNA insert containing the putative fucosyltransferase catalytic domain was isolated from pCDM7- $\alpha(1,3 / 1,4)$ FT. This fragment was treated with the Klenow fragment of DNA polymerase I to create blunt ends, which were ligated to phosphorylated double-stranded linkers $\left(5^{\prime}\right.$-CGGAATTCCG-3'). The ligated fragment was gel-purified, digested with EcoRI, and gel-purified again. This fragment was inserted at the unique EcoRI site pPROTA (Sanchez-Lopez et al. 1988). One plasmid [pPROTA- $\alpha\left(1,3 / 1,4 \mid \mathrm{FT}_{\mathrm{c}}\right.$ ], containing a single insert in the appropriate orientation, was analyzed by DNA sequencing to confirm the predicted sequence across the junctions between the vector, linker, and insert (Fig. 8).

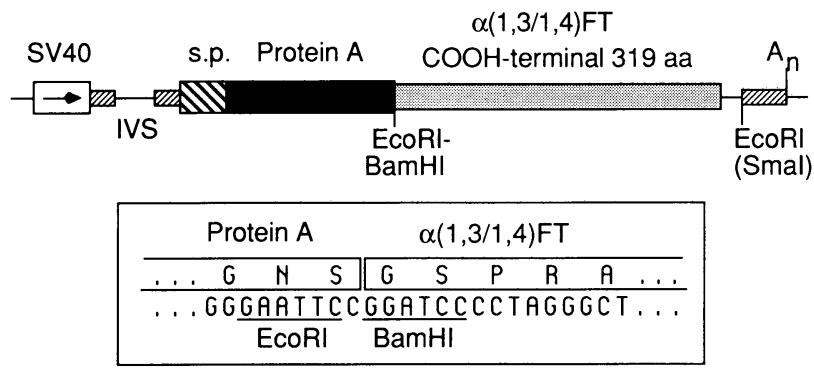

Figure 8. pPROTA- $\alpha(1,3 / 1,4) \mathrm{FT}_{\mathrm{c}}$ fusion vector construction. The vector pPROTA- $\alpha(1,3 / 1,4) \mathrm{FT}_{\mathrm{c}}$ consists of DNA sequences corresponding to amino acids 43 through 361 of the $\alpha(1,3 /$ $1,4 \mid$ FT protein sequence fused in-frame to the IgG-binding domain of Staphylococcal aureus protein A (Experimental procedures). (s.p.) Transin signal peptide sequences; (SV40) SV40 early gene promoter sequences. Sequences denoted by hatched regions indicate sections of the vector derived from rabbit $\beta$ globin sequences, including segments containing an intervening sequence (IVS) and a polyadenylation signal $\left(A_{N}\right)$. The SmaI restriction site used to isolate the catalytic domain from pCDM7- $\alpha(1,3 / 1,4) \mathrm{FT}$, which was destroyed during the construction, is noted in parentheses. The DNA sequence across the fusion junction and its derived amino acid sequence (insert). The EcoRI site derived from the synthetic linker, and the BamHI site used to isolate the catalytic domain, are underlined. 
Plasmids pPROTA- $\alpha(1,3 / 1,4) \mathrm{FT}_{\mathrm{c}}$ pCDM7- $\alpha(1,3 / 1,4) \mathrm{FT}$, or pPROTA, (50 $\mu \mathrm{g}$ each) were introduced separately into COS-1 cells $(500,000$ per $100-\mathrm{mm}$ dish) by DEAE-dextran-mediated transfection (Davis et al. 1986). After a 72-hr expression period, the medium $(10 \mathrm{ml})$ was harvested from each plate and subjected to low speed $(300 \mathrm{~g}$ for $8 \mathrm{~min}$ ) and high speed $(100,000 \mathrm{~g}$ for $1 \mathrm{hr}$ ) centrifugations. The supernatants were then adjusted to $0.05 \%$ Tween 20 and were either assayed directly, or were used in IgG-Sepharose or Sepharose binding studies. IgG-Sepharose or Sepharose $6 \mathrm{~B}$ were preequilibrated as described by the manufacturer (Pharmacia) and then equilibrated in $10 \%$ fetal calf serum in Dulbecco's modified Eagle medium (FCS/DMEM). Aliquots of processed supernatants containing known amounts of enzyme activity ("Applied" activity, Table 3) prepared from transfected COS-1 cells were incubated batchwise with $100 \mu \mathrm{l}$ of equilibrated IgG-Sepharose or Sepharose 6B, overnight at $4^{\circ} \mathrm{C}$. Supernatants were saved for assay ("flowthrough" activity, Table 3). The matrices were then washed by centrifugation, 9 times with $1 \mathrm{ml}$ of $50 \mathrm{mM}$ Tris $(\mathrm{pH} 7.5), 1 \mathrm{mg} / \mathrm{ml}$ bovine serum albumin, twice with $1 \mathrm{ml}$ of $20 \mathrm{~mm}$ Tris $(\mathrm{pH} 7.5), 5 \mathrm{~mm} \mathrm{CaCl}$, $0.05 \%$ Tween 20 , and once with FCS/DMEM. The matrices were then resuspended in an equal volume of FCS/DMEM. This suspension was used directly for assay of $\alpha(1,3) \mathrm{FT}$ activity ("bound" activity, Table 3).

\section{Acknowledgments}

We thank Brian Seed for the gift of pCDM7, and for helpful suggestions. We appreciate the careful manuscript review and helpful suggestions provided by Drs. Craig Thompson, Jeff Leiden, Jeff Bonadio, David Ginsburg, Richard Cummings, and David Smith. Dr. Lowe is an Assistant Investigator of the Howard Hughes Medical Institute.

Sequence data described in this paper have been submitted to the EMBL/GenBank data libraries under accession number X53578.

The publication costs of this article were defrayed in part by payment of page charges. This article must therefore be hereby marked "advertisement" in accordance with 18 USC section 1734 solely to indicate this fact.

\section{References}

Aruffo, A. and B. Seed. 1987. Molecular cloning of a CD28 cDNA by a high-efficiency COS cell expression system. Proc. Natl. Acad. Sci. 84: 8573-8577.

Bayna, E.M., J.H. Shaper, and B.D. Shur. 1988. Temporally specific involvement of cell surface $\beta-1,4$ galactosyltransferase during mouse embryo morula compaction. Cell 53: 145157.

Beyer, T.A., J.E. Sadler, J.I. Rearick, J.C. Paulson, and R.L. Hill. 1982. Glycosyltransferases and their use in assessing oligosaccharide structure and structure-function relationships. Adv. Enzymol. 52: 23-175.

Bird, J.M. and S.J. Kimber. 1984. Oligosaccharides containing fucose linked $\alpha(1-3)$ and $\alpha(1-4)$ to $N$-acetylglycosamine cause decompaction of mouse morulae. Dev. Biol. 104: 449-460.

Brederode, J. and G. van Nigtevecht. 1975. Dominance relationships between two allelic genes controlling glycosyltransferases with different substrate specificity in Melandrium. Genetics 77: 507-520.

Childs, R.A., M. Gregoriou, P. Scudder, S.J. Thorpe, A.R. Rees, and T. Feizi. 1984. Blood group-active carbohydrate chains on the receptor for epidermal growth factor of A431 cells. $E M B O$ I. 3: 2227-2233.

Clausen, H., T. White, K. Takio, K. Titani, M. Stroud, E.
Holmes, J. Karkov, L. Thim, and S.-I. Hakomori. 1990. Isolation to homogeneity and partial characterization of a histoblood group A defined Fuc $\alpha 1->2 \mathrm{Gal} \alpha 1->3-N$-acetylgalactosaminyltransferase from human lung tissue. J. Biol. Chem. 265: 1139-1145.

D'Agostaro, G., B. Bendiak, and M. Tropak. 1989. Cloning of cDNA encoding the membrane-bound form of bovine $\beta 1,4-$ galactosyltransferase. Eur. J. Biochem. 183: 211-217.

Davis, L.G., M.D. Dibner, and J.F. Battey. 1986. Basic methods in molecular biology. Elsevier Pub. Co., New York, New York.

de Jong, W.W., W. Hendriks, J.W.M. Mulders, and H. Bloemendal. 1989. Evolution of eye lens crystallins: the stress connection. Trends Biochem. Sci. 14: 365-373.

Devereux, J., P. Haeberli, and O. Smithies. 1984. A comprehensive set of sequence analysis programs for the VAX. Nucleic Acids Res. 12: 387-395.

Dodd, J. and T.M. Jessell. 1985. Lactoseries carbohydrates specify subsets of dorsal root ganglion neurons projecting to the superficial dorsal horn of rat spinal cord. I. Neurosci. 5: 3278-3294.

Eggens, I., B. Fenderson, T. Toyokuni, B. Dean, M. Stroud, and S.-I. Hakomori. 1989. Specific interaction between Le $^{\mathbf{x}}$ and $\mathrm{Le}^{\mathrm{x}}$ determinants. A possible basis for cell recognition in preimplantation embryos and in embryonal carcinoma cells. I. Biol. Chem. 264: 9476-9484.

Eppenberger-Castori, S., H. Lotscher, and J. Finne. 1989. Purification of the $N$-acetylglucosaminide $\alpha(1-3 / 4)$ fucosyltransferase of human milk. Glycoconjugate J. 6: 101-114.

Ernst, L.K., V.P. Rajan, R.D. Larsen, M.M. Ruff, and J.B. Lowe. 1989. Stable expression of blood group $H$ determinants and GDP-L-fucose: $\beta$-D-Galactoside $2-\alpha$-L-fucosyltransferase in mouse cells after transfection with human DNA. $J$. Biol. Chem. 264: 3436-3447.

Feinberg, A.P. and B. Vogelstein. 1983. A technique for radiolabeling DNA restriction endonuclease fragments to high specific activity. Anal. Biochem. 132: 6-13.

Feizi, T. 1985. Demonstration by monoclonal antibodies that carbohydrate structures of glycoproteins and glycolipids are onco-developmental antigens. Nature 314: 53-57.

Fenderson, B.A., U. Zehavi, and S. Hakomori. 1984. A multivalent lacto- $N$-fucopentaose III-lysyllysine conjugate decompacts preimplantation mouse embryos, while the free oligosaccharide is ineffective. J. Exp. Med. 160: 1591-1596.

Fenderson, B.A., E.H. Holmes, Y. Fukushi, and S.-I. Hakomori. 1986. Coordinate expression of $\mathrm{X}$ and $\mathrm{Y}$ haptens during murine embryogenesis. Dev. Biol. 114: 12-21.

Fukuda, M., J.-L. Guan, and J.K. Rose. 1988. A membrane-anchored form but not the secretary form of human chorionic gonadotropin- $\alpha$ chain acquires polylactosaminoglycan. $J$. Biol. Chem. 263: 5314-5318.

Gooi, H.C., T. Feizi, A. Kapadia, B.B. Knowles, D. Solter, and M.J. Evans. 1981. Stage-specific embryonic antigen involves $\alpha 1->3$ fucosylated type 2 blood group chains. Nature 292: $156-158$.

Hagopian, A. and E.H. Eylar 1968. Glycoprotein biosynthesis: studies on the receptor specificity of the polypeptidyl: $N$ acetylgalactosaminyl transferase from bovine submaxillary glands. Arch. Biochem. Biophys. 128: 422-433.

Hakomori, S.-I. 1984. Tumor-associated carbohydrate antigens. Annu. Rev. Immunol. 2: 103-126.

Hall, A.K., R. Nelson, and U. Rutishauser. 1990. Binding properties of detergent-solubilized NCAM. I. Cell Biol. 110: 817-824.

Hirt, B. 1967. Selective extraction of polyoma DNA from infected mouse cell cultures. J. Mol. Biol. 26: 365-369. 
James, D.E., M. Strube, and M. Mueckler. 1989. Molecular cloning and characterization of an insulin-regulatable glucose transporter. Nature 338: 83-87.

Jelinek, W.R., T.P. Toomey, L. Leinwand, C.H. Duncan, P.A. Biro, P.V. Choudary, S.M. Weissman, C.M. Rubin, C.M. Houck, P.L. Deininger, and C.W. Schmid. 1980. Ubiquitous, interspersed repeated sequences in mammalian genomes. Proc. Natl. Acad. Sci. 77: 1398-1402.

Johnson, P.H. and W.M. Watkins. 1982. Separation of an $\alpha-3-L-$ fucosyltransferase from the blood-group-Le-gene specified $\alpha-3 / 4-\mathrm{L}$-fucosyltransferase in human milk. Biochem. Soc. Trans. 10: 445-446.

Johnson, P.H., A.D. Yates, and W.M. Watkins. 1981. Human salivary fucosyltransferases: evidence for two distinct $\alpha-3-\mathrm{L}$ fucosyltransferase activities one of which is associated with the Lewis blood group Le gene. Biochem. Biophys. Res. Commun. 100: 1611-1618.

Joziasse, D.H., J.H. Shaper, D.H. Van den Eijnden, A.J. Van Tunen, N.L. Shaper. 1989. Bovine $\alpha 1->3-$ Galactosyltransferase: isolation and characterization of a cDNA clone. $J$. Biol. Chem. 264: 14290-14297.

Kim, Y.S., S.H. Itzkowitz, M. Yuan, Y.-S. Chung, K. Satake, K. Umeyama, and S.-I. Hakomori. 1988. Le $\mathrm{L}^{\mathrm{x}}$ and Le $\mathrm{Le}^{\mathrm{y}}$ antigen expression in human pancreatic cancer. Cancer Res. 48: 475-482.

Kimber, S.J. 1986. Distribution of lectin receptors in postimplantation mouse embryos at 6-8 days gestation. Am. I. Anat. 177: 203-219.

Kobata, A. 1972. Isolation of oligosaccharides from human milk. Methods Enzymol. 28: 262-271.

Kojima, N. and S.-I. Hakomori. 1989. Specific interaction between gangliotriaosylceramide $\left(\mathrm{Gg}_{3}\right)$ and sialosyllactosylceramide $\left(G_{M_{3}}\right)$ as a basis for specific cellular recognition between lymphoma and melanoma cells. I. Biol. Chem. 264: 20159-20162.

Kornfeld, R. and S. Kornfeld. 1985. Assembly of asparaginelinked oligosaccharides. Annu. Rev. Biochem. 54: 631-664.

Kozak, M. 1984. Selection of initiation sites by eucaryotic ribosomes: effect of inserting AUG triplets upstream from the coding sequence for preproinsulin. Nucleic Acids Res. 12: 3873-3893.

1989. The scanning model for translation: An update. $J$. Cell Biol. 108: 229-241.

Kumar, R. and P. Stanley. 1989. Transfection of a human gene that corrects the Lecl glycosylation defect: Evidence for transfer of the structural gene for $\mathrm{N}$-acetylglucosaminyltransferase I. Mol. Cell. Biol. 9: 5713-5717.

Kyte, J. and R.F. Doolittle. 1982. A simple method for displaying the hydropathic character of a protein. J. Mol. Bio. 157: 105-132.

Larsen, R.D., V.P. Rajan, M.M. Ruff, J. Kukowska-Latallo, R.D. Cummings, and J.B. Lowe. 1989. Isolation of a cDNA encoding a murine UDP galactose: $\beta$-D-galactosyl-1,4- $N$ acetyl-D-glucosaminide $\alpha$-1,3-galactosyltransferase: expression cloning by gene transfer. Proc. Natl. Acad. Sci. 86: 8227-8231.

Larsen R.D., L.K. Ernst, R.P. Nair, and J.B. Lowe. 1990a. Molecular cloning, sequence, and expression of a human GDP-Lfucose: $\beta$-D-galactoside $2-\alpha$-L-fucosyltransferase cDNA that can form the $\mathrm{H}$ blood group antigen. Proc. Natl. Acad. Sci. 87: (in press).

Larsen, R.D., C.A. Rivera-Marrero, L.K. Ernst, R.D. Cummings, and J.B. Lowe. 1990b. Frameshift and nonsense mutations in a human genomic sequence homologous to a murine UDPGal: $\beta$-D-Gal(1,4)-D-GlcNAc $\alpha(1,3)$-galactosyltransferase. $I$. Biol. Chem. 265: 7055-7061.
Le Beau, M.M., D. Ryan, Jr., and M.A. Pericak-Vance. 1989. Report of the committee on the genetic constitution of chromosomes 18 and 19, Human Gene Mapping 10 (1989): Tenth International Workshop on Human Gene Mapping. Cytogenet. Cell Genet. 51: 338-357.

Liener, I.E., N. Sharon, and I.J. Goldstein. 1986. The lectins. Properties, functions, and applications in biology and medicine. Academic Press, Orlando, Florida.

Mellis, S.J. and J.U. Baenziger. 1981. Separation of neutral oligosaccharides by high-performance liquid chromatography. Anal. Biochem. 114: 276-280.

Miller, D.A., O.J. Miller, V.G. Dev, S. Hashmi, R. Tantravahi, L. Medrano, and H. Green. 1974. Human chromosome 19 carries a poliovirus receptor gene. Cell 1: 167-173.

Montreuil, J. 1960. Nouvelles acquisitions sur les oligosides naturels. Bull. Soc. Chim. Biol. 42: 1399-1427.

Mueckler, M., C. Caruso, S.A. Baldwin, M. Panico, I. Blench, H.R. Morris, W.J. Allard, G.E. Lienhard, and H.F. Lodish. 1985. Sequence and structure of a human glucose transporter. Science 229: 941-945.

Paulson, J.C. and K.J. Colley. 1989. Glycosyltransferases. Structure, localization, and control of cell type-specific glycosylation. J. Biol. Chem. 264: 17615-17618.

Pennington, J.E., S. Rastan, D. Roelcke, and T. Feizi. 1985. Saccharide structures of the mouse embryo during the first eight days of development. Inferences from immunocytochemical studies using monoclonal antibodies in conjunction with glycosidases. J. Embryol. Exp. Morphol. 90: 335361.

Ponder, B.A.J., M.F.W. Festing, and M.M. Wilkinson. 1985. An allelic difference determines reciprocal patterns of expression of binding sites for Dolichos biflorus lectin in inbred strains of mice. J. Embryol. Exp. Morphol. 87: 229-239.

Potvin, B., R. Kumar, D.R. Howard, and P. Stanley. 1990. Transfection of a human $\alpha-(1,3)$ fucosyltransferase gene into chinese hamster ovary cells. Complications arise from activation of endogenous $\alpha-(1,3)$ fucosyltransferases. I. Biol. Chem. 265: 1615-1622.

Prieels. J.-P., D. Monnom, M. Dolmans, T.A. Beyer, and R.L. Hill. 1981. Co-purification of the Lewis blood group $N$ acetylglucosaminide $\alpha 1->4$ fucosyltransferase and an $N$-acetylglucosaminide $\alpha 1->3$ fucosyltransferase from human milk. J. Biol. Chem. 256: 10456-10463.

Rajan, V.P., R.D. Larsen, S. Ajmera, L.K. Ernst, and J.B. Lowe. 1989. A cloned human DNA restriction fragment determines expression of a GDP-L-fucose: $\beta$-D-Galactoside $2-\alpha-L-$ fucosyltransferase in transfected cells. Evidence for isolation and transfer of the human $\mathrm{H}$ blood group locus. J. Biol. Chem. 264: 11158-11167.

Rauvala, H., J.-P. Prieels, and J. Finne. 1983. Cell adhesion mediated by a purified fucosyltransferase. Proc. Natl. Acad. Sci. 80: 3991-3995.

Reitman, M.L., I.S. Trowbridge, and S. Kornfeld. 1980. Mouse lymphoma cell lines resistant to pea lectin are defective in fucose metabolism. J. Biol. Chem. 255: 9900-9906.

Rigby, P.W., M. Dieckmann, C. Rhodes, and P. Berg. 1977. Labeling deoxyribonucleic acid to high specific activity in vitro by nick translation with DNA polymerase I. J. Mol. Biol. 113: 237-251.

Ripka, J.M., M. Pierce, and N. Fregien. 1989. DNA-mediated transformation of $\mathrm{N}$-acetylglucosaminyltransferase I activity into an enzyme deficient cell line. Biochem. Biophys. Res. Commun. 159: 554-560.

Roseman, S. 1970. The synthesis of complex carbohydrates by multiglycosyltransferase systems and their potential func- 
tion in intercellular adhesion. Chem. Phys. Lipids 5: 270297.

Rutishauser, U., A. Acheson, A.K. Hall, D.M. Mann, and J. Sunshine. 1988. The neural cell adhesion molecule (NCAM) as a regulator of cell-cell interactions. Science 240: 53-57.

Sadler, J.E. 1984. Biosynthesis of glycoproteins; formation of Olinked oligosaccharides. In Biology of carbohydrates. (ed. V. Ginsburg and P.W. Robbins), pp. 200-287, John Wiley and Sons, New York, New York.

Sanchez-Lopez, R., R. Nicholson, M.-C. Gesnel, L.M. Matrisian, and R. Breathnach. 1988. Structure-function relationships in the collagenase family member transin. I. Biol. Chem. 263: 11892-11899.

Sanger, F., S. Nicklen, and A.R. Coulson. 1977. DNA sequencing with chain-terminating inhibitors. Proc. Natl. Acad. Sci. 74: 5463-5467.

Seed, B. 1987. An LFA-3 cDNA encodes a phospholipid-linked membrane protein homologous to its receptor CD2. Nature 329: 840-842.

Seed, B. and A. Aruffo. 1987. Molecular cloning of the CD2 antigen, the T-cell erythrocyte receptor, by a rapid immunoselection procedure. Proc. Natl. Acad. Sci. 84: 3365-3369.

Shaper, N.L., G.F. Hollis, J.G. Douglas, I.R. Kirsch, and J.H. Shaper. 1988. Characterization of the full length cDNA for murine $\beta$-1,4-galactosyltransferase. Novel features at the $5^{\prime}$ end predict two translational start sites at two in-frame AUGs. J. Biol. Chem. 263: 10420-10428.

Shur, B.D. 1983. Embryonal carcinoma cell adhesion: The role of surface galactosyltransferase and its $90 \mathrm{~K}$ lactosaminoglycan substrate. Dev. Biol. 99: 360-372.

Solter, D. and B.B. Knowles. 1978. Monoclonal antibody defining a stage-specific mouse embryonic antigen (SSEA-1). Proc. Natl. Acad. Sci. 75: 5565-5569.

Spiess, M. and H.F. Lodish. 1986. An internal signal sequence: the asialoglycoprotein receptor membrane anchor. Cell 44: 177-185.

Stanley, P. 1984. Glycosylation mutants of animal cells. Annu. Rev. Genet. 18: 525-552.

Szulman, A.E. 1960. The histological distribution of blood group substances A and B in man. J. Exp. Med. 111: 785800.

- 1962. The histological distribution of the blood group substances in man as disclosed by immunofluorescence. II. The $\mathrm{H}$ antigen and its relation to $\mathrm{A}$ and $\mathrm{B}$ antigens. J. Exp. Med. 115: 977-996.

- 1963. The histological distribution of the blood group substances in man as disclosed by immunofluorescence. III. The A,B, and $\mathrm{H}$ antigens in embryos and fetuses from 18 $\mathrm{mm}$ in length. J. Exp. Med. 119: 503-523.

- 1965. The ABH antigens in human tissues and secretions during embryonal development. J. Histochem. Cytochem. 13: 752-754.

- 1971. The histological distribution of the blood group substances in man as disclosed by immunofluorescence. IV. The $\mathrm{ABH}$ antigens in embryos at the fifth week post fertilization. Human Pathol. 2: 575-585.

Szulman, A.E. and D.M. Marcus. 1973. The histologic distribution of the blood group substances in man as disclosed by immunofluorescence. VI. The $\mathrm{Le}^{\mathrm{a}}$ and $\mathrm{Le}^{\mathrm{b}}$ antigens during fetal development. Lab. Invest. 28: 565-574.

Tetteroo, P.A.T., H.T. de Heij, D.H. Van den Eijnden, F.J. Visser, E. Schoenmaker, and A.H.M. Geurts van Kessel. 1987. A GDP-fucose: [Gal $\beta 1->4]$ GlcNAc $\alpha 1->3$-fucosyltransferase activity is correlated with the presence of human chromosome 11 and the expression of the $\mathrm{Le}^{\mathrm{x}}, \mathrm{Le}^{\mathrm{y}}$, and Sialyl-Le ${ }^{x}$ antigens in human-mouse cell hybrids. J. Biol.
Chem. 262: 15984-15989.

Walter, P. and G. Blobel. 1983. Signal recognition particle: A ribonucleoprotein required for cotranslational translocation of proteins, isolation and properties. Methods Enzymol. 96: $682-691$.

Watkins, W.M. 1980. Biochemistry and genetics of the $\mathrm{ABO}$, Lewis, and $\mathrm{P}$ blood group systems. Adv. Hum. Genet. 10: $1-116$.

Weinstein, J., U. Souza-e-Silva, and J.C. Paulson. 1982. Purification of Gal $\beta 1->4$ GlcNAc $\alpha 2->6$ Sialyltransferase and a Gal $\beta 1->3(4)$ GlcNAc $\alpha 2->3$ sialyltransferase to homogeneity from rat liver. J. Biol. Chem. 257: 13835-13844.

Weinstein, J., E.U. Lee, K. McEntee, P.-H. Lai, and J.C. Paulson. 1987. Primary structure of $\beta$-galactoside $\alpha 2,6$-sialyltransferase. Conversion of membrane-bound enzyme to soluble forms by cleavage of the $\mathrm{NH}_{2}$-terminal signal anchor. J. Biol. Chem 262: 17735-17743.

Wickner, W.T. and H.F. Lodish. 1985. Multiple mechanisms of protein insertion into and across membranes. Science 230: $400-407$.

Wysocki, L.J. and V.L. Sato. 1978. "Panning" for lymphocytes: A method for cell selection. Proc. Natl. Acad. Sci. 75: 2844-2848.

Yamamoto, F.-I., J. Marken, T. Tsuji, T. White, H. Clausen, and S.-I. Hakomori. 1990. Cloning and characterization of DNA complementary to human UDP-GalNAc:Fuc $\alpha 1->2 \mathrm{Gal}$ $\alpha 1->3$ GalNAc transferase (histo-blood group A transferase) mRNA. J. Biol. Chem. 264: 1146-1151. 


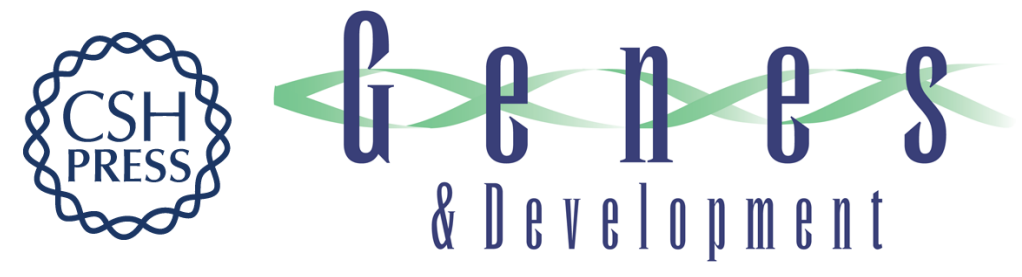

\section{A cloned human cDNA determines expression of a mouse stage-specific embryonic antigen and the Lewis blood group alpha(1,3/1,4)fucosyltransferase.}

J F Kukowska-Latallo, R D Larsen, R P Nair, et al.

Genes Dev. 1990, 4:

Access the most recent version at doi:10.1101/gad.4.8.1288

References This article cites 80 articles, 37 of which can be accessed free at:

http://genesdev.cshlp.org/content/4/8/1288.full.htmI\#ref-list-1

License

Email Alerting Receive free email alerts when new articles cite this article - sign up in the box at the top

Service right corner of the article or click here.

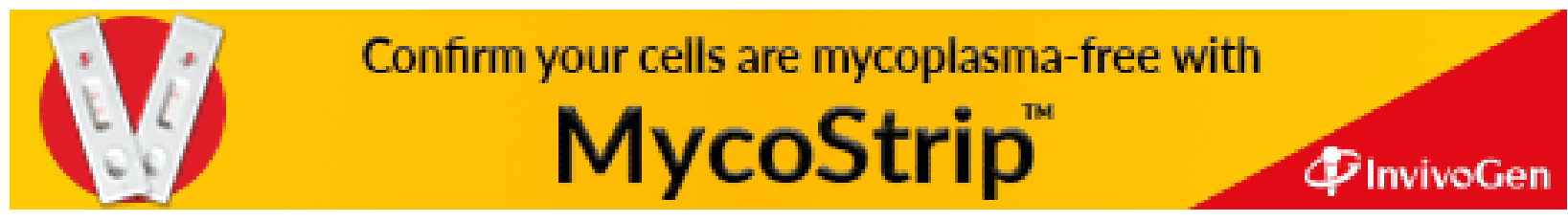

